\title{
Environmental costs of buildings: monetary valuation of ecological indicators for the building industry
}

\author{
Patricia Schneider-Marin ${ }^{1}$ (i) $\cdot$ Werner Lang ${ }^{1}$
}

Received: 20 March 2020 / Accepted: 22 June 2020 / Published online: 27 July 2020

(C) The Author(s) 2020

\begin{abstract}
Purpose Building life cycle assessment (LCA) draws on a number of indicators, including primary energy (PE) demand and global warming potential (GWP). A method of constructing a composite index of weighted individual indicators facilitates their use in comparisons and optimization of buildings, but a standard for weighting has not been established. This study investigates the use of monetary valuation of building LCA results as a way to weigh, aggregate, and compare results.

Methods A set of six recent German office buildings served as a case study. For these, standard LCA and life cycle cost (LCC) calculations were conducted. Monetary valuation models from the literature were investigated as a basis for evaluation. From these, maximum and minimum valuation was chosen and applied to the LCA results for the embedded impacts of the case study buildings. The buildings' environmental costs (EC) were thereafter calculated and contributions of single impacts are analyzed. The EC - based on external costs - are subsequently compared with the life cycle costs (LCC) — based on market prices — of the respective buildings. Results and discussion Of the five standard environmental indicators used in Germany, GWP contributes approximately 80 to $95 \%$ of the overall EC. Acidification potential (AP) is the second largest contributor with up to 18\%. Eutrophication (EP), photochemical oxidization (POCP), and ozone depletion potential (ODP) contribute less than $2.0 \%, 1.05 \%$, and $2.4 \mathrm{E}-6 \%$ respectively. An additional assessment of the contribution of resource depletion to EC shows an impact at least as large as the impact of GWP. The relation between the EC and LCC strongly depends on the EC model used: if EC are internalized, they add between 1 and $37 \%$ to the life cycle costs of the buildings. Varying construction materials for a case study building shows that materials with low GWP have the potential to lower environmental costs significantly without a trade-off in favor of other indicators.

Conclusions Despite their sensitivity to the monetary valuation model used, EC provide an indication that GWP and resource depletion - followed by AP - are the most relevant of the environmental indicators currently considered for the construction industry. Monetary valuation of environmental impacts is a valuable tool for comparisons of different buildings and design options and provides an effective and valuable way of communicating LCA results to stakeholders.
\end{abstract}

Keywords Building life cycle assessment $\cdot$ LCA $\cdot$ Monetary valuation of environmental impacts $\cdot$ Environmental life cycle cost . Weighting in LCA · Comparative LCA · Building life cycle cost $\cdot$ LCC

\section{Introduction and problem statement}

Responsible editor: Holger Wallbaum

Electronic supplementary material The online version of this article (https://doi.org/10.1007/s11367-020-01784-y) contains supplementary material, which is available to authorized users.

Patricia Schneider-Marin

patricia.schneider@tum.de

1 Institute of Energy Efficient and Sustainable Design and Building, TUM Department of Civil, Geo and Environmental Engineering, TUM Department of Architecture, Technical University of Munich (TUM), Arcisstr. 21, 80333 Munich, Germany
The building industry is one of the major contributors to climate change and the consumption of the earth's resources. In this context, life cycle assessment (LCA) is being established as a method of evaluating the environmental quality of buildings (Weissenberger et al. 2014), as it assesses environmental impact for their entire life cycle. As the use of life cycle assessment (LCA) is adapted to buildings, it is facing multiple challenges. Originally, LCA was designed for evaluating and optimizing industrial products (Klöpffer and Grahl 2009) that are usually made in batch production. Buildings, on the contrary, are almost exclusively prototypes and consist of a multitude of products and services. Hence, each individual 
building needs a custom LCA, requiring detailed knowledge about the building in question. To simplify building LCAs, they are, with very few exceptions, calculated on the basis of aggregated product data in lieu of single processes, as LCA calculations would otherwise demand too much time, be open to calculation errors, and lack comparability.

In Germany, building LCA calculations use the publicly available database Ökobaudat (Bundesministerium des Innern, für Bau und Heimat (BMI) 2016). This database contains LCI (life cycle inventory) and LCIA (life cycle impact assessment) data for over 1000 different building products and buildingrelated processes. Each product or process is evaluated in terms of 8 input categories (e.g., energy, material), 8 output categories (e.g., exported energy, waste), and 7 environmental impact categories (e.g., global warming potential (GWP), acidification potential (AP)). The choice of indicators contained in Ökobaudat originates from LCA's original application in product development. Therefore, it might not reflect those environmental problems for which the building industry is most relevant for, but is simply a consequence of data availability.

Consequently, the full results of building LCA studies containing all individual 23 indicators are difficult to comprehend for stakeholders in the building industry. The multitude of indicators does not lend itself readily to decision-making in the planning process as the indicators show a variety of issues: various environmental problems, resource consumption, and waste generation. These are measured in terms of incommensurable units and, in addition, might show very different tendencies depending on the building materials used. Therefore, results for different indicators often contradict each other. Overall optimization is thus impossible when different indicators do not share a common measure of evaluation and move independently of one another.

A widely used work-around is restricting the assessment to one or a few indicators that are deemed most crucial, for instance, global warming potential and/or primary energy use (non-renewable/renewable). The obvious downside is that other potentially important environmental impacts are ignored and trade-offs involving them cannot be considered (Ströbele 2013).

The nature of the building design process requires multi-criteria decision-making support and optimization of many aspects such as structural safety, fire safety, and costs. In such an inevitably complex context especially, a simple, readily comprehensible, single indicator of environmental impacts would enable decision-makers to take such impacts into consideration-where, in the absence of such an indicator, environmental impacts, for practical reasons, often are ignored, in part or entirely. In this regard, Kägi et al. (2016) argue that there is a "need for end-point or single-score assessment (and transparent communication of the same) for sound and effective decision-making support."
The basic structure and rules for LCA are specified in DIN EN ISO 14040 and DIN EN ISO 14044. DIN EN ISO 14044 does not allow for a weighting of indicators in publicly available comparative LCA studies (DIN Deutsches Institut für Normung e.V. 2009). Nevertheless, several methods provide end-point and/or single-score conversion of LCA results in order to make indicators commensurable and thereby LCA results comparable and easier to understand for stakeholders (Pizzol et al. 2017). The weighting step is a value choice of the stakeholders and hence has to be carefully considered (Steen 2006; Bengtsson and Steen 2000). End-point systems, such as ReCiPe (Goedkoop et al. 2013) or UBP (Ahbe 2014), establish a scoring system that assesses the potential damage (or benefit) to humans, ecosystems, and resources. Building certification systems, such as the $\mathrm{DGNB}^{1}$ system, assign percentage values to the indicators, e.g., $40 \%$ to GWP. These percentage values are choices of the respective certification system and reflect the relative importance of an indicator assigned by the certification organization. Single-score systems aggregate either LCIA data and/or mid-point indicators, e.g., the Austrian OI3 (IBO - Österreichisches Institut für Bauen und Ökologie GmbH 2016), or end-point indicators to a single value allowing comparison of options.

Monetary valuation of LCA results (Fig. 1) is such a singlescore indicator method that is increasingly used by stakeholders, as it provides ecological costs (EC) as an easy-tounderstand basis for decisions. Its main critique is that it is regarded as questionable from a sustainability accounting point of view: assigning monetary values to environmental problems might suggest that by paying for the "cost" of the pollution, it is possible to compensate for the impact of the pollution in question (Vogtländer and Bijma 2000). It is thus criticized to be an instrument of "weak" sustainability, as it suggests that monetary means can compensate for the loss of ecological quality (Rennings and Wiggering 1997). Monetary valuation methods should take this critique seriously and always reveal their background and purpose.

Monetary valuation's advantage is that it can provide valuable information to stakeholders and policy makers when assessing the overall environmental quality of projects, products, or services (Swarr et al. 2011). In addition, monetary valuation facilitates comparing EC to current market prices of products and services. Moreover, assigning monetary values to environmental factors enables environmental criteria to be taken into account in business decisions (Reid et al. 2005) and it can be applied in cost-benefit analyses.

None of the existing monetary valuation methods is specifically geared towards LCA in the building industry. Adensam et al. (2002) have previously studied monetary valuation of environmental impacts of buildings applying (fixed) cost

\footnotetext{
${ }^{1}$ Deutsche Gesellschaft für nachhaltiges Bauen; German Sustainable Building Council
} 


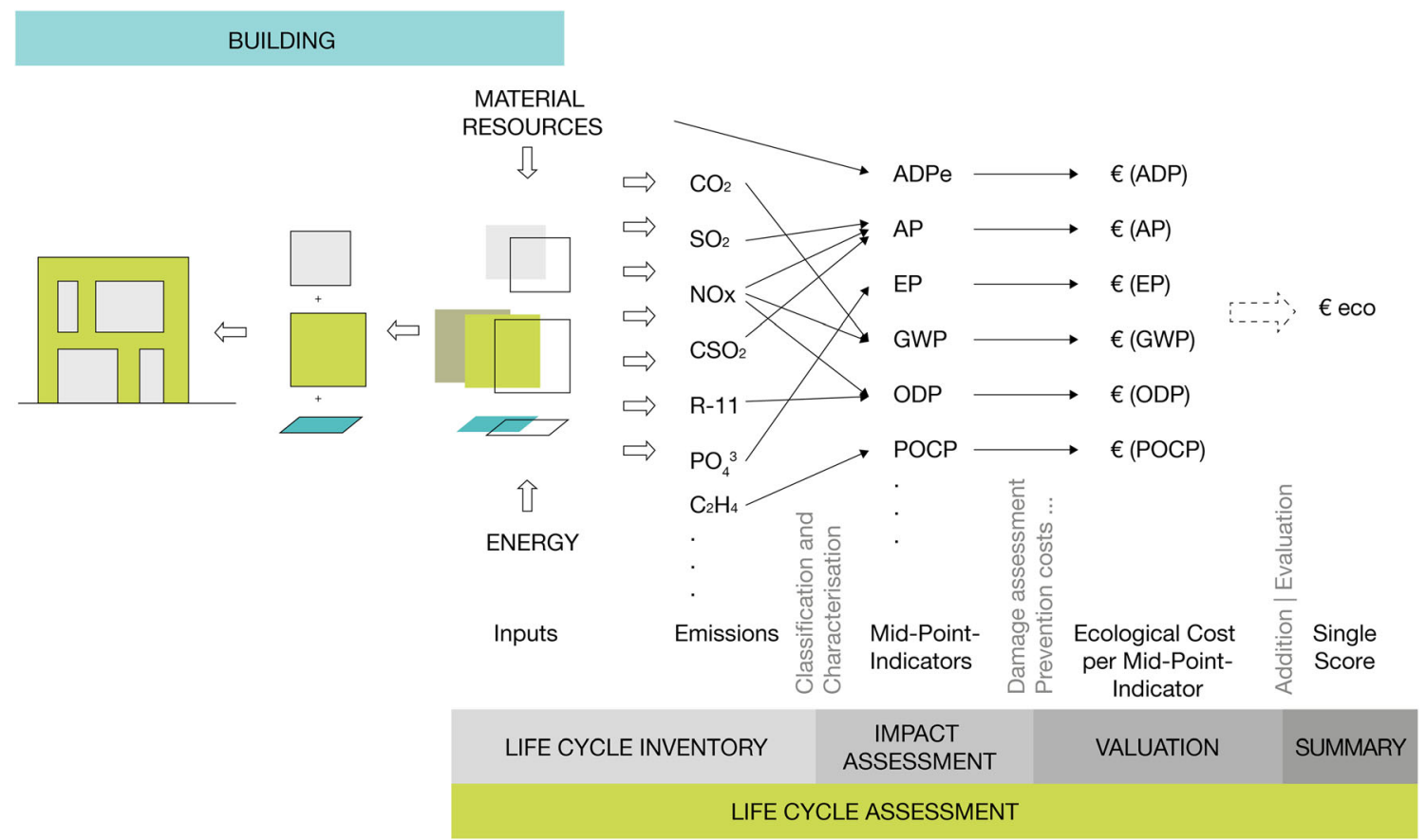

Fig. 1 Building LCA and monetary valuation of mid-point indicators to arrive at a single score

parameters to two sample projects. The study concludes that the external costs of the building materials amount to approximately $3 \%$ of the two sample buildings' construction cost and that, based on the Austrian database used, $\mathrm{CO}_{2}$ pricing has the greatest influence. Ulmer et al. (2010) take their valuations for ODP, POCP, and EP from Adensam et al. (2002) and use Friedrich et al. (2007) valuations of AP and GWP in their study of six (residential) sample projects. They conclude that internalizing external costs increases construction costs by an average of approximately $35 \%$, differing from Adensam et al. (2002) by a factor of more than 10. This is in part due to the fact that primary energy demand is valued in addition to environmental indicators, but, to a larger extent, including the external costs for the energy demand during building operation (phase B6) causes this significantly higher value. They agree with Adensam et al. (2002) that GWP valuation highly influences results. To our knowledge, no analysis exists of how using a different valuation set affects the assessment and influences the search for more sustainable solutions. In addition, previous studies relate external costs mainly to construction costs, but do not align the life cycle phases considered for external costs to those considered for life cycle costs of the respective buildings.

Since construction costs or, in the context of sustainability, life cycle costs of buildings are an important criterion in the design process, calculating the monetary value of environmental impacts to find the most cost-efficient environmentally friendly solution fits well into the logic of design decisions. However, unlike in the Netherlands, where a monetary valuation system for buildings and civil engineering works has been established (Building Quality
Foundation 2019), monetary valuation is not common practice in building LCA studies in Germany.

A monetary valuation approach in the construction industry has a two-fold advantage:

- Aggregation of a multitude of environmental indicators into one, easy-to-understand measure

- Comparability of alternative solutions in terms of economic and ecological aspects

\section{Research goals}

This study applies different EC models to the embedded environmental impacts of six German office buildings. As aggregating all environmental impacts to one value allows for direct comparison but at the same time loses the detailed information about single mid-points, we keep this information by showing the EC per mid-point-indicator. The results reveal the weights monetary valuation assigns to the different indicators and which environmental indicators are deemed the most significant for building construction. This offers the possibility of reevaluating the choice of currently used indicators in light of the particularities of the building industry, as it shows those impacts caused by construction that have a greater influence than others with respect to the chosen indicators.

Showing ranges of valuation makes it clear that EC assessment of buildings is quite dependent on the valuation methods applied and the resulting weighting of each impact category, while also indicating areas of the greatest potential for further 
research into the monetary valuation of environmental impacts of buildings. In addition, we investigate whether the valuation has an influence on the ranking of different building projects when comparing their environmental impacts.

Comparing environmental costs (i.e., external costs) to the life cycle costs (i.e., market prices) of the respective building shows how significant environmental pricing could be for various building parts and/or life cycle phases. It raises the question if and under which circumstances the internalization of external costs could lead to a more environmentally friendly solution by expressing its value in monetary terms and potentially tipping the business scale towards a solution with less environmental impact.

There is significant potential to improve the environmental quality of buildings if LCA is applied in the planning process. As LCA results are communicated to non-expert users in this process, it is vital for environmental issues to be as easily and unequivocally understood as possible to avoid their being partly or entirely ignored. This does not, of course, prevent more complex background information and methodological choices (e.g., relative weights of indicators) from being provided to expert users.

\section{Methods}

\subsection{Life cycle assessment}

Life cycle assessment in general consists of the four steps of goal and scope definition, inventory, impact assessment, and interpretation (DIN Deutsches Institut für Normung e.V. 2009). The goal of this study is the comparison of environmental impacts of a sample set of six different construction projects (see Section 3.4). The scope of the LCA study is aligned with the framework provided in the German sustainable building certification systems $\mathrm{DGNB}^{1}$ and BNB. ${ }^{2}$ These prescribe a study period of 50 years and reference service lives according to Bundesinstitut für Bau-, Stadt- und Raumforschung (BBSR) im Bundesamt für Bauwesen und Raumentwicklung (BBR) (2011). They also entail that inputs, outputs, and environmental impacts are calculated for life cycle phases A1-A3, B4, C3, and C4 (Fig. 2) according to DIN 15978 (DIN Deutsches Institut für Normung e.V. 2012). As phase D is only included in overall sums for the DGNB system, it is investigated separately. For this study, the embedded impacts of the buildings' construction are calculated excluding the buildings' operational phase (B6) and their mechanical, electrical, and plumbing (MEP) systems. The inventory includes all building parts for which the execution drawings

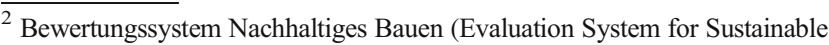
Building)
}

provide information and excludes materials with a share of less than $1 \%$ of overall building mass.

Impact assessment includes the classification of emissions, i.e., the grouping of emissions according to their impact on the environment. The following step, characterization, entails assigning a factor to each substance in relation to the reference substance for the corresponding environmental impact. There are a number of methods for this characterization step, which are continuously further developed and refined. Ökobaudat, the database used for this study, prescribes a characterization method for each impact category included in the database by referencing DIN 15804 (DIN Deutsches Institut für Normung e.V. 2014).

This LCA study is concerned with environmental impacts and does not include social LCA, wider benefits, or other considerations of sustainability. Hence, environmental impact categories of DIN EN 15804 (DIN Deutsches Institut für Normung e.V. 2014) are evaluated with their corresponding characterization factors. LCAs are calculated on the basis of the German database Ökobaudat, version 2016-I, using the tool eLCA. ${ }^{3}$ When data was not available in the Ökobaudat 2016-I, we draw on external data (e.g., data for carpets and glue were taken from Ökobaudat 2019-III). For purposes of the analysis, the structure of the cost groups of DIN 276 (Deutsches Institut für Normung e.V. 2008) is applied to the LCA results. We excluded the use of other databases, as this can skew results (Mahler and Schneider 2017).

In order to make the buildings, which are of different sizes, comparable, results are normalized to $1 \mathrm{~m}^{2}$ usable floor area (UFA). The reference study period used for comparisons, including the building use phase, is 50 years. We worked with fixed scenarios and background data for both LCA and LCC to investigate the influence of monetary valuation on the overall ecological cost independently of LCA/LCC uncertainties.

\subsection{Monetary valuation of environmental impacts}

The recently established ISO 14008 (monetary valuation of environmental impacts and related environmental aspects) provides a framework for monetary valuation (International Organization for Standardization 2019) and shows that the method of monetary valuation of environmental impacts has attained recognition internationally.

Monetary valuation of environmental impacts determines currency values, sometimes denoted as the "shadow price" (Bickel and Friedrich 2005), of environmental damages (or benefits) caused by economic activities such as constructing, maintaining, and disassembling an office building, the subject of this study. Environmental impacts include impacts to ecosystems, human health, or human possessions. If damages caused and/or benefits accrued are not compensated for, they are known in environmental economics as externalities.

\footnotetext{
${ }^{3}$ www.bauteileditor.de
} 


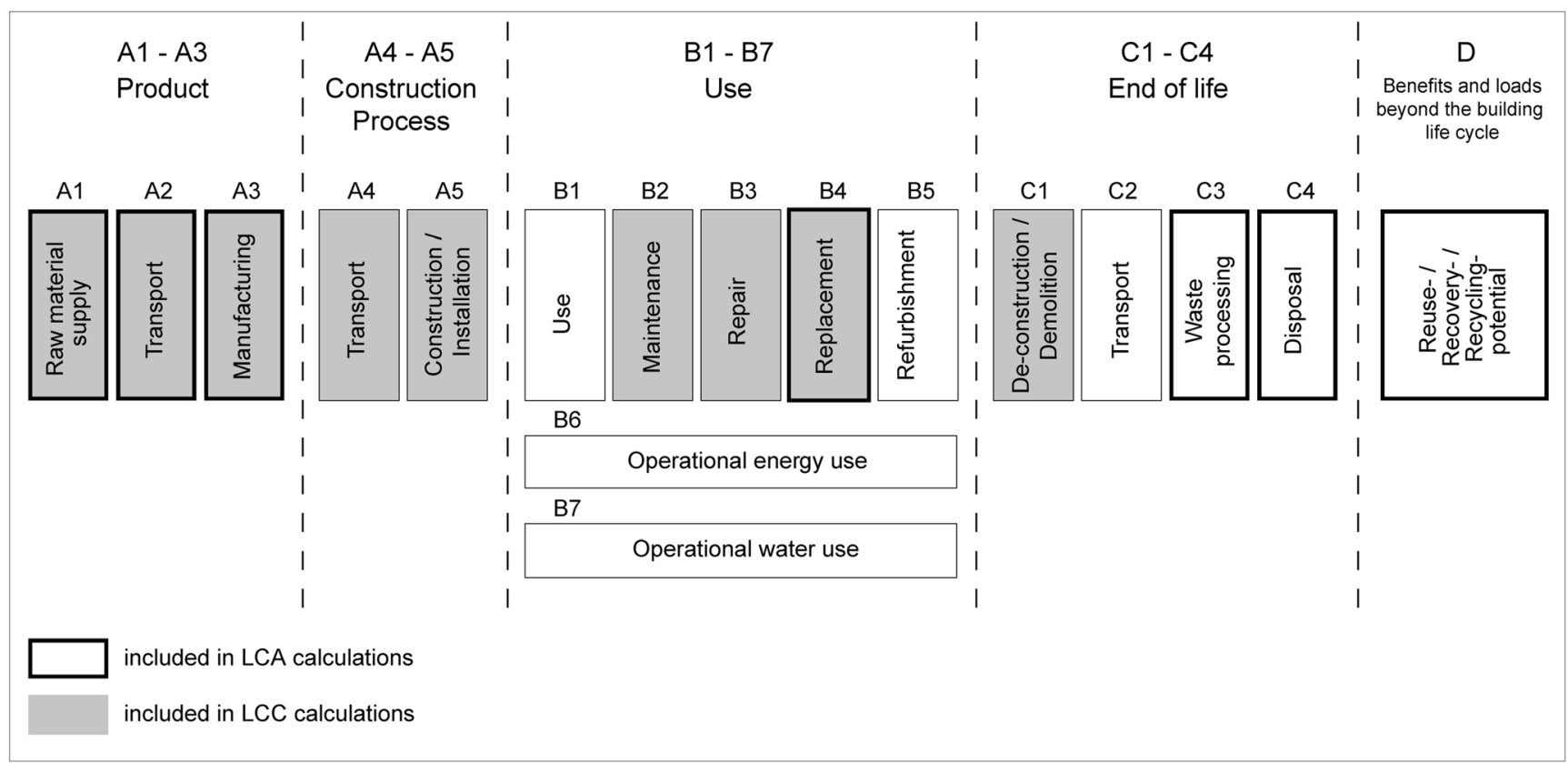

Fig. 2 Life cycle phases according to BS EN 15978 (British Standards Institution 2011), highlighting of phases considered in LCA/LCC calculations by authors

Although these externalities are not included in the (market) price of the product, several methods of quantifying them exist. Tekie and Lindblad (2013) provide a comprehensive overview. Not all monetary valuation methods are equally applicable to LCA studies (Pizzol et al. 2015), as LCA requires the valuation specifically of environmental impacts.

Valuation can be applied at different steps in the LCIA (Fig. 3 ). Some methods quantify directly the cost of emissions by assessing the external cost caused by the emission of single substances, e.g., the method used by the ExternE project (Bickel and Friedrich 2005). It is also possible to valuate impacts at midpoint, as done by Vogtländer (2017). Other methods provide values for end-point categories, e.g., Weidema (2009), Murakami et al. (2018), with or without disaggregation into corresponding mid-points. As Ökobaudat, the database used for this study, provides aggregated mid-point-indicators without full inventory data, we are limited to valuation systems providing values for mid-point indicators. There are overlaps with the systems that provide costs of emissions directly (Fig. 3: "unit conversion"), when the reference substance for a mid-point indicator is valuated, such as $\mathrm{SO}_{2}$ (reference substance for acidification potential). Ideally, the characterization factors (CF) for the substances contributing to a mid-point indicator are identical with the ratio of the costs of emissions of the substances in question, or $\mathrm{CF}($ substance $\mathrm{A})=\mathrm{EC}$ (substance $\mathrm{A}) / \mathrm{EC}$ (reference substance). To give an example, the sum of the cost of $\mathrm{SO}_{2}$ and $\mathrm{NO}_{x}$ emitted by a process should equal the cost of acidification potential measured in $\mathrm{SO}_{2}$-equivalent. This only holds true if the characterization model and the unit conversion (nomenclature from ISO 14008 (International Organization for Standardization 2019)) are aligned.
We do not propose a new valuation set but rather vary the monetary values within the range provided by previous studies in order to analyze which weights result for the different impact categories. Additionally, large uncertainties are inherent within monetary valuation methods (Pizzol et al. 2015). This study gives an indication as to which differences in valuation play an important role for the resulting weighting in building LCA calculations. The studies and methods considered for this study are shown in Table 5 .

A number of methods have been developed to assess external costs of environmental problems or qualities either by quantifying willingness to pay (WTP) or avoidance costs (Ahlroth et al. 2011). WTP can be revealed (e.g., damage costs), expressed (stated preference), imputed (e.g., substitution), or politically determined (e.g., in terms of taxes) (Ahlroth et al. 2011; Mishra 2006). Revealed WTP uses market prices as a basis. To determine expressed WTP, surveys need to be conducted in which individuals are asked to state their preferences, e.g., their WTP to avoid a marginal deterioration in environmental quality or quality of life. Imputed WTP methods investigate the prices an individual is willing to pay for the replacement of an environmental good or service or to avoid damages to it. Lastly, taxes can be used to estimate external costs, as they represent society's WTP to reach environmental targets (Finnveden et al. 2006). Avoidance, prevention, or abatement costs are calculated costs for measures that avoid emissions, e.g., the use of renewable energy sources in lieu of fossil energy sources in order to avoid $\mathrm{CO}_{2}$ emissions. For avoidance costs, a target amount of emissions and either average or marginal costs to reach the set target need to be defined. There are differences between countries in how the economic value of damages and/or 


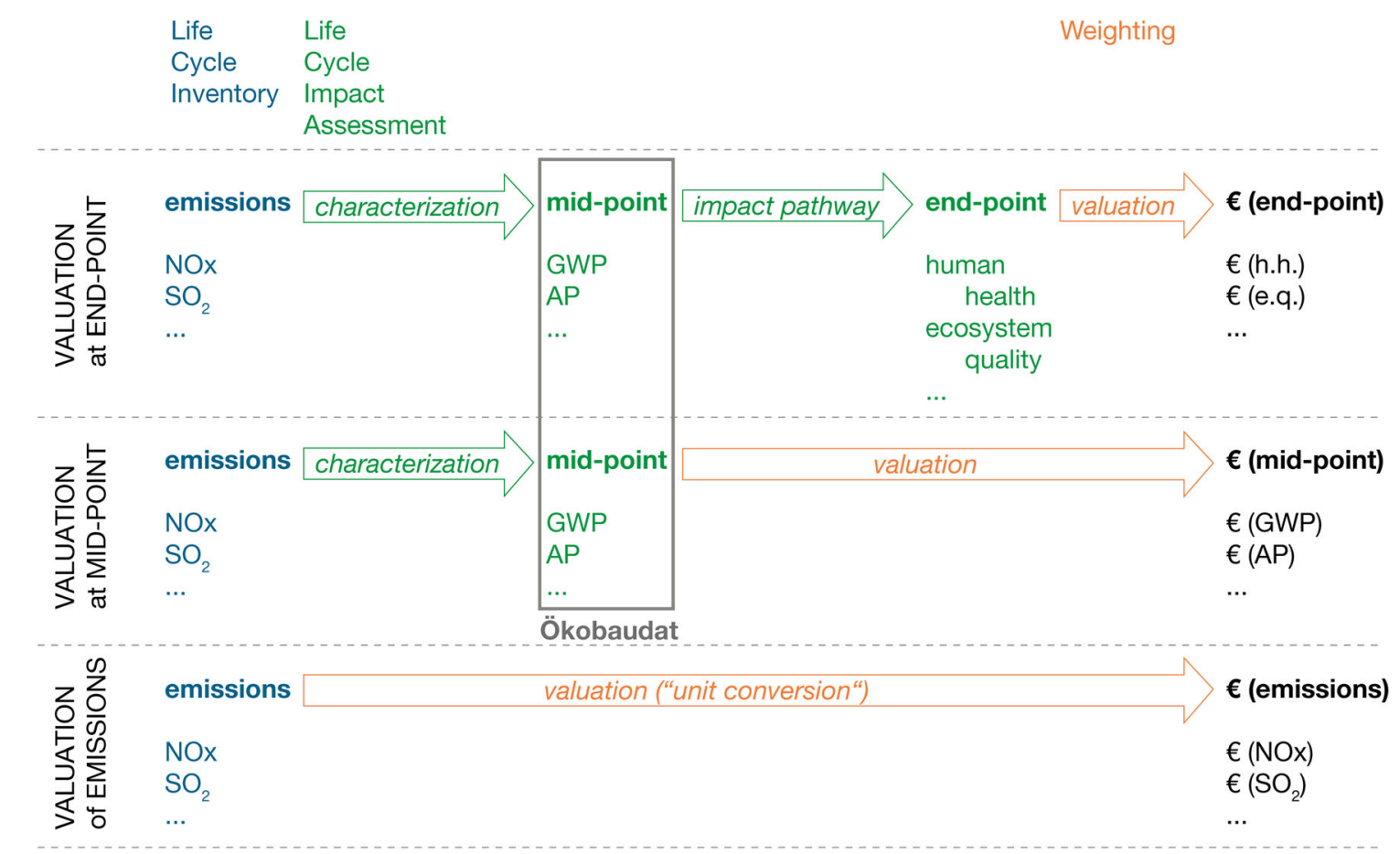

Fig. 3 Monetary valuation at different levels of aggregation in life cycle impact assessment (LCIA)

avoidance is assessed, i.e., equity weighting. Likewise, the question of whether and how future emissions should be discounted is answered differently. Hellweg et al. (2003) recommend that discounting should be subject to sensitivity analysis.

For this study, we consider environmental criteria, i.e., results from the LCIA. As energy is an input value into the system (Fig. 1) and therefore part of the life cycle inventory, it is not considered in our study. Adding a valuation for energy consumption double counts the valuation of the environmental impacts caused by energy consumption for the materials contained in the building. Comparing a monetary valuation of the mid-point impacts to a monetary valuation of the energy consumption related to the production and end of life of building materials is subject of further research. However, for the valuation of resources, we do consider the primary energy contained in a material (PENRM), as this energy is not consumed and hence has no environmental impact other than resource depletion.

\subsubsection{Valuation of mid-point impacts}

For this study, we draw a worst-case scenario for determining the maximum values of the environmental costs of the building: for this, we apply the greatest valuation found in literature for the mid-point indicator in question. As such, we determine if a high value for one impact category would lead to a more significant contribution to the overall external cost from the same. On the other end of the spectrum, we utilize the minimum values calculated in recent studies to define a best-case scenario, yielding a range of estimates. Table 1 shows the values used. If applicable, values were inflation adjusted per (OECD 2019) to the base year 2015 to match the LCC study. This method accepts the fact that the resulting minimum and maximum values mix different valuation models. The goal is to determine the effect of higher/lower valuation of environmental impacts in order to prioritize the reduction of uncertainty in valuation.

As the effects of global warming gain political importance, global warming potential (GWP) is by far the most discussed indicator in the recent literature. Twelve recent valuation models were considered for this study in conjunction with $\mathrm{CO}_{2}$ pricing models currently on the market, such as the European Union Emissions Trading System (EU ETS), and implied pricing derived from NGOs offering $\mathrm{CO}_{2}$ compensation for individual emissions, e.g., atmosfair (Germany) and MyClimate (Switzerland). The minimum valuation considered in this study ${ }^{4}$ is the recent pricing for $\mathrm{CO}_{2}$ compensation by atmosfair (atmosfair gGmbH 2019). This valuation is low because compensation projects seek out the most cost-efficient, "low-hanging fruits" for $\mathrm{CO}_{2}$ prevention (Schultz et al. 2015). As, in nominal terms, this price has not changed from 2007 until now, we use this valuation for our study. In

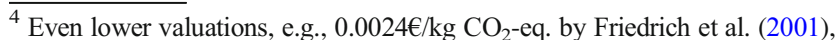
were not used here, as such low assessments largely seem to reflect the dates of these studies and appear outdated, as more recent updated (higher) values have become available for each system. Likewise, the recent $\mathrm{CO}_{2}$-pricing plan issued by the German government BMU (2019) starting at $0.01 € / \mathrm{kg} \mathrm{CO}_{2}$ emissions for transport and space heating in 2020 was excluded as it does not apply to the embedded emissions in the building sector. Lastly, the EU ETS was excluded as prices for the certificates are highly volatile.
} 
Table 1 Monetary valuation of mid-point indicators used in this study; global warming potential (GWP), ozone depletion potential (ODP), photochemical creation potential (POCP), acidification potential (AP), eutrophication potential (EP)

\begin{tabular}{llllll}
\hline $\begin{array}{l}\text { Environmental } \\
\text { indicator }\end{array}$ & Unit & $\begin{array}{l}\text { Min. valuation } \\
\text { per unit }\end{array}$ & Source of min. valuation & $\begin{array}{l}\text { Max. valuation } \\
\text { per unit }\end{array}$ & Source of max. valuation \\
\hline GWP & kg CO2-eq. & $0.02 €$ & atmosfair gGmbH 2019 & $0.65 €$ & Matthey and Bünger (2019) \\
ODP & kg R11-eq.; kg FCKW-eq.; & $0.00 €$ & Vogtländer 2016 & $30.00 €$ & the Bruyn et al. (2018) \\
Pg CFC11-eq. & kg C2H4 eq. & $0.28 €$ & Adensam et al. 2002 & $10.02 €$ & Vogtländer (2016) \\
POCP & kg SO2-eq. & $1.77 €$ & Adensam et al. 2002 & $15.04 €$ & $\begin{array}{c}\text { Bünger and Matthey (2018), } \\
\text { Matthey and Bünger (2019) }\end{array}$ \\
EP & kg PO43-eq. & $1.78 €$ & Adensam et al. 2002 & $18.52 €$ & Ahlroth (2009) \\
\hline
\end{tabular}

reality, the fact that the nominal price has not been adjusted implies that the inflation-adjusted price for the compensation of $\mathrm{CO}_{2}$ emissions has decreased over the last 13 years. The highest valuation for the emission of greenhouse gases is taken from a recent report issued by the German Federal Environmental Agency (Matthey and Bünger 2019) and represents the (maximum) value recommended for sensitivity analyses with a base year of 2016. This valuation model does not discount future emissions and makes its evaluation based on a damage cost model.

Ozone depletion potential (ODP) is not intensely discussed in the recent literature, as the Montreal protocol has successfully regulated and reduced ozone-depleting substances. The eco-cost-value ratio (EVR) model by Vogtländer et al. (2001) valuates $1 \mathrm{~kg} \mathrm{CFC11-equiv.} \mathrm{at} \mathrm{zero} \mathrm{eco-cost} \mathrm{(Vogtländer}$ 2016), as the substances causing ozone depletion are accounted for in the global warming prevention costs (Vogtländer 2017). This model determines marginal prevention costs, which do not allow for double counting and always use the higher valued prevention costs. The highest valuation is taken from the Bruyn et al. (2018), who valuate $1 \mathrm{~kg}$ CFC11-equiv. at $30.00 €$. Their model uses ReCiPe characterization factors in conjunction with the NEEDs model. The costs in this method are prevention costs, defined as "the highest permissible cost level ... for the government per unit of emission control" (the Bruyn et al. 2018). It is tailored to Dutch conditions and has to be modified for use in Germany, especially if ODP proves to be a relevant indicator considering the maximum values in this study. When using the maximum valuation for ODP and GWP in this study, there could be some double counting of the effects of emissions causing both ozone depletion and global warming. This has to be kept in mind when evaluating the results.

The remaining three categories differ from GWP and ODP insofar as they cause local rather than global effects. Therefore, resulting potential damages are more traceable but are also dependent on local circumstances, such as population density, the state of the local economy, or the type of adjacent land use.
The potential for summer smog or the formation of tropospheric ozone known as POCP (Photochemical Ozone Creation Potential) is considered to cause respiratory diseases and damage to agriculture and forests. The model of Adensam et al. (2002) values POCP lower than all other studies considered. Their valuation includes health costs caused by exposure to high ozone values. The authors state that additional potential damage to agricultural production and forestry is currently not quantifiable. Vogtländer (2016) values the marginal prevention costs of POCP significantly higher. As this contradicts the theory that prevention is more economical than repair, it seems to suggest that the damage costs might be valued too low or incompletely by the former model. Nevertheless, we used them as the lowest estimate for the EC of POCP.

For Acidification Potential (AP) and Eutrophication Potential (EP), the lowest values are again from Adensam et al. (2002). Both values represent the costs of damage. For AP, these include damage to human health, forests, and buildings. EP also causes health costs as it influences drinking water quality. Potential economic disadvantages to tourism caused by the eutrophication of water bodies were not quantified. The high estimate of the EC of AP is from Matthey and Bünger (2019). They valuate $\mathrm{SO}_{2}$ emissions using the average damage costs of air pollution (emission) by unknown sources. Characterization was applied according to DIN 15804 (DIN Deutsches Institut für Normung e.V. 2014), as no conversion is available in the study. The upper limit for EP is taken from (Ahlroth 2009), representing damage cost estimates using individual willingness to pay and market prices.

The range of values of the environmental impacts is surprisingly large. All studies stress the high degree of variance in damage or prevention cost models. But, with the exception of Ahlroth (2009), who provides minimum and maximum values for abiotic resources, GWP, POCP and human toxicity, and some studies using minimum and maximum values for GHG emissions, none of the studies cited provides a range of values for all indicators. ${ }^{5}$

\footnotetext{
${ }^{5}$ The ranges provided by Ahlroth (2009) lie within the ranges considered in this study.
} 


\subsubsection{Valuation of resources}

As the building sector consumes a large share of the world's resources (Klaassens 2014; Hegger et al. 2012), resource consumption is an indicator that should be considered when evaluating the ecological qualities of buildings. The question of whether and how to assess resources within the LCA framework is subject to controversy, and different methods have been developed for this assessment (Klinglmair et al. 2014; Giljum et al. 2011). As the extraction of natural resources affects the ecosystem and at the same time provides the basis for human economic activities, a complete valuation includes economic, socioeconomic, and ecological aspects. If resource depletion is evaluated from an ecological point of view, it relates to the overall (natural) availability of a given resource. Economic evaluation includes scarcity by relating the resource to the total stock available with current and/or future technologies of extraction. Socioeconomic aspects focus on a combination of a resource's scarcity and its importance to society to assess how critical it is.

Environmental impacts of resource extraction should be assessed in the impact assessment, whereas economic and social impacts should be modeled separately (Weidema et al. 2005). As life cycle phase A1 assesses environmental impacts from resource extraction itself, they are already included in the above life cycle assessment. Therefore, the valuation of resources in addition to the five impact categories described in Section 3.2.1 includes resource depletion as related to the natural availability of resources only. Van Oers and Guinée (2016) argue that ADPE/ADP elem (abiotic depletion of elements) is therefore the only purely environmental indicator to be included in LCA calculations.

We calculate the ecological costs related to resource depletion separately from the costs of emissions to analyze the potential weight this indicator takes in building LCA evaluation. Ökobaudat (Bundesministerium des Innern, für Bau und Heimat (BMI) 2016) provides values for ADPF (abiotic depletion of fossil energy sources) in Megajoule (MJ) and $\mathrm{ADP}_{\text {elem }}$ in $\mathrm{kg}$ antimony-equivalents (Sb-eq.) as indicators of resource depletion. Both of these indicators are related to abiotic resources only and take into account the overall resource stock (DIN Deutsches Institut für Normung e.V. 2014). The underlying methodology and characterization was developed by the Institute of Environmental Sciences (CML) (van Oers et al. 2002). An updated indicator has been developed by van Oers and Guinée (2016), but is not included in Ökobaudat yet.

Little data is available regarding the valuation of resource depletion. The work-around suggested by Vogtländer (2016) is to value the non-renewable primary energy embedded in the material (PENRM) where detailed data about the resource depletion related to a particular material is not available. We use this as a test value to determine the relative weight of this indicator. Alternatively, evaluation of the depletion of antimony $(\mathrm{Sb})$, the reference substance for $\mathrm{ADP}_{\text {elem }}$, can be found in the EPS 2015d method (Steen and Palander 2016). This valuation (Table 2) is applied and results are compared.

\subsection{Life cycle costs}

Life cycle cost (LCC) calculations consider all costs related to the entire life cycle of the building, i.e., initial investment, costs during operation, and demolition costs. They are based on market prices and subject to price increases and discounting. For the life cycle of buildings, we use the life cycle phases according to DIN 15978 (DIN Deutsches Institut für Normung e.V. 2012) (Fig. 2) to align LCC with LCA calculations. Building life cycle costs (LCC) include construction, use and end of life - that is, life cycle phases A1-A3, B2-B4, and C1. Phases A4 and A5 are indirectly included in construction cost as they are generally included in the contractors' prices. For the same reason, they are not listed separately. Standardized data for C3, C4, and D is currently not available by product but is estimated on a building level. For the parameters discounting and price increase, the BNB certification system framework is used with an annual $2 \%$ price increase for building materials and services and a $1.5 \%$ discount rate for the evaluation of future investments. The base year used is 2015, the same as for the LCA calculations.

LCC reflect market prices for building products and services. In light of the presence of the European Emissions Trading System (EU ETS) for greenhouse gases, the question arises if some or all of the external costs of GHG emissions have already been internalized and are therefore included in the life cycle costs of buildings. Freeman et al. (1992) argue that tradable emission permits ensure the internalization of externalities under optimal trading rules (i.e., the marginal damage is equal for all sources). This means that the EU ETS would ensure that the external costs of GWP are already factored into the LCC. Under this circumstance, the price of the permit proves to be the marginal avoidance cost, as emitting facilities will avoid emissions if this can be achieved at a lower price than buying permits (Freeman et al. 1992). Although the first condition applies, as greenhouse gases cause the same amount of global warming regardless of their source, the EU ETS does not adhere to optimal trading rules. Firstly, in 2015, the base year of this study, the manufacturing industry received on average $66 \%$ of certificates free of charge

Table 2 Valuation of abiotic resource depletion $* 1$ ELU (environmental load unit) $=1 €_{2016}$

\begin{tabular}{lll}
\hline Indicator & Valuation & Source \\
\hline PENRM & $0.0167 € / \mathrm{MJ}$ & Vogtländer (2016) \\
ADPelem & $18,190 \mathrm{ELU} / \mathrm{kg} \mathrm{Sb} *$ & Steen and Palander (2015) \\
\hline
\end{tabular}


(European Commission 2020). Secondly, this percentage varies significantly between industries, insofar as industries subject to an exposure to carbon leakage received emissions certificates equal to their predicted emissions free of charge. This applies to most of the industries manufacturing construction materials, e.g., the manufacturing of cement, steel, aluminum, and glass (European Commission 2014). Therefore, it is concluded for the purpose of this study that the external costs of direct GHG emissions caused by the manufacturing of construction materials have not been factored into the LCC. However, as power generators in most EU countries including Germany have to buy emission allowances, manufacturing processes buying electricity are subject to indirect price increase due to GHG emissions of electricity generation. Unfortunately, data to track the electricity used by the manufacturing of construction materials is not available. Therefore, we excluded this factor from this study also considering the low price of traded certificates in 2015 (between 7 $€$ and $8 €$ per ton of $\mathrm{CO}_{2}$-eq).

In order to normalize results and make them comparable to the LCA results, we used the usable floor area (UFA) as the functional equivalent, although LCC studies per the BNB framework use the gross floor area. The reference study period is the same as for the LCA calculation: 50 years. As the purpose of the LCC assessment in this study is to provide comparison values for the external costs, the same constant boundary conditions as for the LCA apply (e.g., products' standard service lives).

\subsection{The case study projects}

A set of six recent office buildings serves as a case study. They were built after 2009 and adhere to the German energy standard EnEV (Energieeinsparverordnung = energy saving ordinance) 2009. The construction type is similar, with concrete as the main structural material and either glazed curtain walls or facades made of concrete with exterior insulation and windows.
For all projects, LCA and LCC calculations were performed according to the framework described in Sections 3.1.and 3.3. Base data for the LCA and LCC calculations of projects $\mathrm{A}$ to $\mathrm{E}$ are taken from a previous study conducted by the authors and colleagues (Schneider-Marin et al. 2019). Figure 4 shows the sizes, number of floors, exterior wall, and roof types of the case study projects. In Table 3, general characteristics of the projects are listed.

Project F, the FTmehrHaus of Tausendpfund $\mathrm{GmbH}$, was calculated additionally for this study providing different material options keeping everything else, e.g., energy standard, spatial organization, and geometry, the same between variations. The built structure uses three different exterior wall types for the three floors, as it serves as a test case for the owner, assessing thermal comfort in spaces with concrete, masonry, and sand-lime brick exterior walls. We varied insulation materials of each of these three wall types (variations F1 to F10) and also calculated 3 different subtypes of a wood frame construction for the exterior wall (variations F11 to F13). For comparison with projects A to E, an exterior glazed curtain wall was considered (variation F14). Greenhouse gas emissions emerged as a preponderant factor in the impact assessment (see Section 4). We therefore also calculated a wood structure (variation F15), adding up to a total of 15 construction material types.

\section{Results}

\subsection{Environmental costs for five mid-point indicators}

The LCA results of the case study project LCAs lay within a range considered acceptable by the DGNB system. For example, results for GWP for life cycle phases A1-A3, B4, C3, C4, and $\mathrm{D}$ lie between $8.32 \mathrm{~kg} \mathrm{CO} / \mathrm{m}^{2} * \mathrm{a}$ and $10.27 \mathrm{~kg}$ $\mathrm{CO}_{2} / \mathrm{m}^{2} *$ a, averaging $9.5 \mathrm{~kg} \mathrm{CO} / \mathrm{m}^{2} *$ a. This is very close to the DGNB benchmark of $9.4 \mathrm{~kg} \mathrm{CO} / \mathrm{m}^{2} * \mathrm{a}$ (DGNB GmbH 2018).

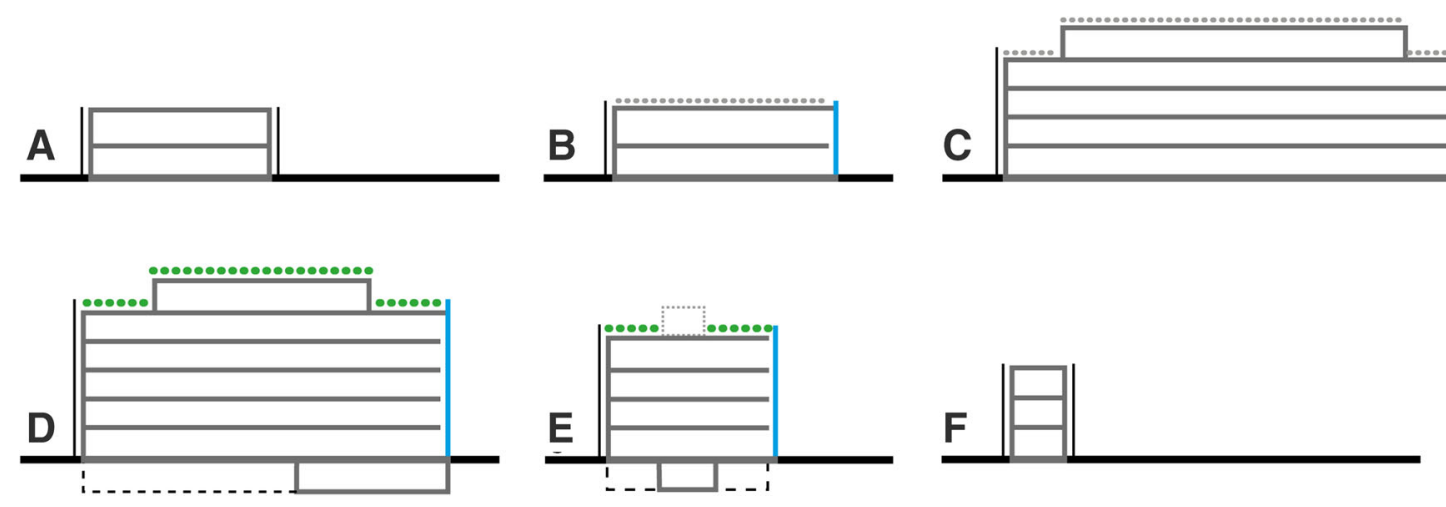

Fig. 4 Simplified representation of the case study projects showing size and number of floors 
Table 3 Characteristics of the sample projects

\begin{tabular}{|c|c|c|c|c|c|c|}
\hline Project & UFA $\left(\mathrm{m}^{2}\right)$ & Number of floors & Structure & Exterior walls & $\begin{array}{l}\text { Window- } \\
\text { to- } \\
\text { wall ratio }\end{array}$ & Energy standard \\
\hline A & 2.512 & 2 & Reinforced concrete & $\begin{array}{l}\text { Reinforced concrete } \\
\text { Exterior cladding: steel } \\
\text { Windows/curtain wall: aluminum frame }\end{array}$ & 0.41 & EnEV 2014 \\
\hline B & 3.039 & 2 & Reinforced concrete & $\begin{array}{l}\text { Reinforced concrete } \\
\text { Exterior cladding: steel } \\
\text { Windows: aluminum frame }\end{array}$ & 0.37 & EnEV 2014 \\
\hline $\mathrm{C}$ & 15.006 & 5 & Reinforced concrete & $\begin{array}{l}\text { Reinforced concrete } \\
\text { Ext. cladding: aluminum } \\
\text { Windows: aluminum frame }\end{array}$ & 0.27 & EnEV 2014 \\
\hline $\mathrm{D}$ & 13.685 & 6 & Reinforced concrete & $\begin{array}{l}\text { Reinforced concrete } \\
\text { Ext. cladding: aluminum } \\
\text { Windows/curtain wall: aluminum frame }\end{array}$ & 0.25 & EnEV 2009 \\
\hline $\mathrm{E}$ & 4.504 & 4 & Reinforced concrete & $\begin{array}{l}\text { Reinforced concrete } \\
\text { Ext. cladding: aluminum/concrete } \\
\text { Windows/curtain wall: aluminum frame }\end{array}$ & 0.28 & EnEV 2014 \\
\hline $\mathrm{F}$ & 1.060 & 3 & Reinforced concrete & $\begin{array}{l}\text { Reinf. concrete, } \\
\text { Ext. cladding: EIFS (EPS) } \\
\text { Windows: PVC frame }\end{array}$ & 0.27 & EnEV 2014 \\
\hline
\end{tabular}

The EC for all sample projects were calculated according to the parameters described in Section 3. They are represented for three choices of life cycle phases: initial material use (product: A1 to A3), whole life cycle including use and end of life (A1 to $\mathrm{A} 3+\mathrm{B} 4+\mathrm{C} 1+\mathrm{C} 3)$, and additionally including endof-life credits (A1 to A3 + B4 + C1 + C3 + D). The environmental impacts are converted into $\mathrm{EC}$ for the minimum and maximum EC values shown in Table 1. In general, most environmental impacts and therefore the larger share of EC occur in the product phases A1 to A3. This can be explained by the assumptions going into the calculations and by the data background: According to Ökobaudat, for all building materials, the product phase causes more environmental impacts than the end-of-life phase. Additionally, life cycle lengths of building materials vary between 15 and 50 years. With the bulk of the materials having a reference service life of 50 years or more, phase B4 causes fewer impacts than A1 to A3. The exchange and end-of-life phases add impact, whereas phase D contains some credits, i.e., overall impact decreases if phase D is considered.

\subsubsection{Minimum valuation}

Figure 5 shows that for the minimum valuation of all indicators, GWP dominates the overall EC for all projects. GWP contributes a minimum of $80 \%$ for phase A1-A3 (project E), $81 \%$ including end of life (projects D, E), and $81 \%$ including phase D (project E) to the overall EC. Its overall contribution can be up to $84 \%$ for phase A1-A3 (project F), $86 \%$ including end of life (project F), and $85 \%$ including phase D (project F).
$\mathrm{AP}$ is the second largest contributor, accounting for a minimum of $14 \%$ of the overall EC for phase A1-A3 (project F), $12 \%$ if end of life is included (project F), and $12 \%$ if phase D is included (project F). It can be responsible for up to $18 \%$ for phase A1-A3 (project E), 17\% if end of life is included (project $\mathrm{D}$ ), and $16 \%$ if phase $\mathrm{D}$ is included (project $\mathrm{E}$ ).

It is interesting to see, however, that accounting for AP does not change the ranking of the projects significantly. Project F emits the least greenhouse gases and also shows the lowest EC whereas project D shows the highest values for both depending on the life cycle phases considered. For the projects in mid-range, A and E, accounting for AP has an influence, as their GWP values are very close. If life cycle phase $\mathrm{D}$ is considered, the ranking changes between projects $\mathrm{C}, \mathrm{E}$, and D, as their GWP values are again within a very close range or even equal. GWP, in other words, is the preponderant factor in determining the ranking of the case study buildings' environmental impact.

ODP does not contribute to the overall EC, as its EC are set to zero. POCP contributes between 0.2 and $0.8 \%$ and EP between 1.5 and $2.0 \%$ for all projects. This indicates that when $\mathrm{EC}$ is set to its minimum value found in the literature, the environmental impacts that should be considered first and foremost when constructing, maintaining, and demolishing buildings are GWP and AP, whereas ODP, POCP, and EP are almost negligible.

\subsubsection{Maximum valuation}

Assuming maximal EC estimations (Fig. 6) does not change this picture fundamentally, although GWP is even more 


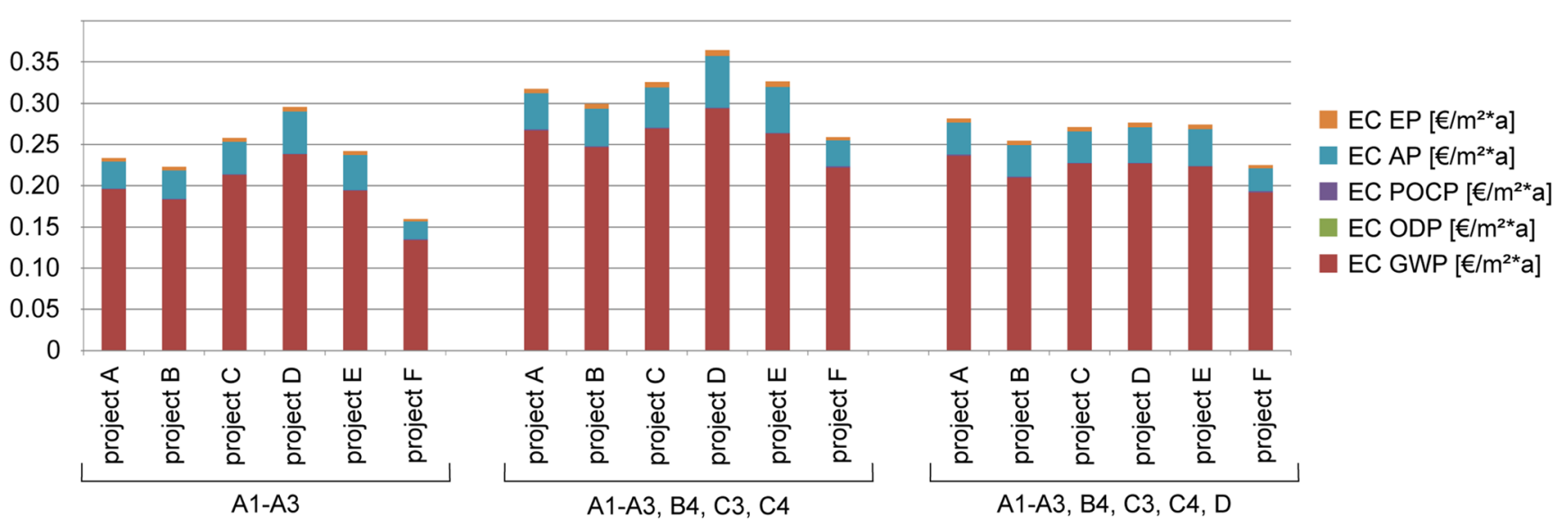

Fig. 5 Total minimum EC of the case study projects in $€$ per $\mathrm{m}^{2}$ UFA and year; subdivided in EC for eutrophication potential (EP), acidification potential (AP), photochemical creation potential (POCP), ozone

depletion potential (ODP), and global warming potential (GWP); corresponding numbers are listed in Table 6

preponderant. GWP contributes between 92 and $94 \%$ to the overall EC, while AP is responsible for between 4 and $6 \%$. Although the valuation of ODP, POCP, and EP is significantly higher than when minimal valuation is assumed (see Table 1), none of these indicators contributes more than $1.2 \%$. This is interesting in light of the question if there might be some double counting of substances that contribute to both GWP and ODP, as we are using maximum valuation for both (see Section 3.2.1). The extremely low contribution of ODP, less than $0.000011 \%$, indicates that, if there is some double counting, it is irrelevant to the overall result.

Using maximum values yields again almost the same ranking of the projects as ranking them according to GWP only, with the exception of projects that emit almost the same amount of GWP per $\mathrm{m}^{2}$ and year. The only differences in ranking that result from including AP are between projects $\mathrm{A}$ and $\mathrm{E}$ for phase A1-A3, projects $\mathrm{A}$ and $\mathrm{C}$ if phase $\mathrm{D}$ is not considered, and, if phase D is considered, projects C, D, and E. None of the other indicators change any rankings.

Comparing minimum and maximum EC assessments, overall EC increase by a factor of 24.6 to 25.8 depending on the projects and the life cycle phases considered. About $93 \%$ of this increase is due to the 28 -fold increase in the valuation of GWP. About 5\% of the variance is due to the 8 -fold increase in the valuation of AP. The large increases of the other indicators (e.g., $\mathrm{EC}_{\max }(\mathrm{POCP})=36 \times \mathrm{EC}_{\min }(\mathrm{POCP}) ; \mathrm{EC}_{\max }$ $\left.(\mathrm{EP})=10 \times \mathrm{EC}_{\min }(\mathrm{EP})\right)$ do not contribute significantly to the overall increase.

\subsubsection{Influence of global warming potential}

As the minimum and maximum valuation reveals the importance of GWP, we reduced GWP valuation to the point

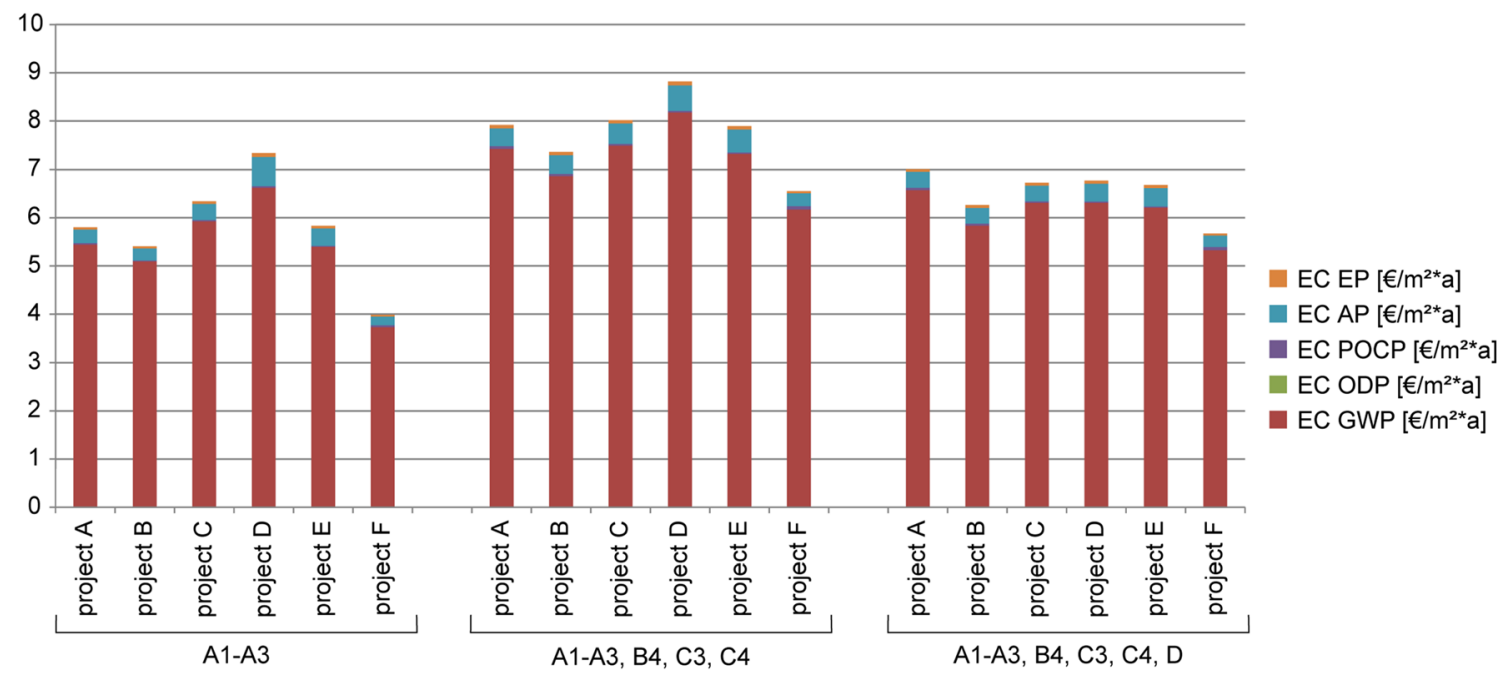

Fig. 6 Total maximum EC of the case study projects in $€$ per $\mathrm{m}^{2}$ UFA and year; subdivided in EC for eutrophication potential (EP), acidification potential (AP), photochemical creation potential (POCP), ozone depletion potential (ODP), and global warming potential (GWP); corresponding numbers are listed in Table 7 
when its EC would cease to be as unequivocally important: GWP's contribution to overall EC is so preponderant that it only drops to about $50 \%$ when GWP's EC is set to $0.039 €$ per $\mathrm{kg} \mathrm{CO} 2$-eq. while all other ECs are kept at their maximal assessments. For this specification, AP contributes 35 to $54 \%$, EP between 6 and $8 \%$, and POCP between 3 and $8 \%$. ODP is still not relevant, with a contribution of $0.000041 \%$ or less to the overall EC. Alternatively, for AP to consistently account for $50 \%$ or more of the overall EC, GWP valuation would have to drop to 0.016 $€$ per kg CO2-eq. The fact that GWP overwhelmingly determines the overall EC of all case study projects also broadly resonates with the fact that building construction contributes approximately $11 \%$ of global $\mathrm{CO}_{2}$ emissions (International Energy Agency (IEA) 2018).

\subsection{Taking resource depletion into account}

In the previous section, Ökobaudat's five indicators directly related to environmental damage were considered. This section tackles the question of, in addition, taking resource depletion into account. Although only a few methods evaluating resource depletion at the mid-point level exist (Section 3.2.2.), an assessment on their basis nonetheless yields insights into the relative importance of this indicator while also highlighting differences in valuation.

Figure 7 shows a comparison between the direct valuation of $\mathrm{ADP}_{\text {elem }}$ and the work-around of valuating PENRM. In general, there are more significant differences between projects on the resource depletion count than on the other indicators considered in Section 4.1. However, the ranking of the projects is entirely dependent on the valuation method used, i.e., it changes almost completely depending on the method. Most notably, irrespective of the phases considered, Project $F$ shows the highest EC using PENRM and the lowest EC of all projects using $\mathrm{ADP}_{\text {elem }}$ while Project $\mathrm{E}$ has the highest $\mathrm{EC}$ using $\mathrm{ADP}_{\text {elem }}$ and the lowest EC using PENRM, i.e., the points of the ranking are reversed. With the exception of project $\mathrm{E}$, valuation of $\mathrm{ADP}_{\text {elem }}$ yields lower $\mathrm{EC}$ results than valuation of PENRM. Lastly, while employing $\mathrm{ADP}_{\text {elem }}$ substantially lowers the cost assessment of all other projects compared with their evaluation using PENRM, this change in method increases the cost assessment of project $\mathrm{E}$.

We also see that, using the PENRM method, life cycle phases A1-A3 cease to be the dominant life cycle phases, with their maximum contribution to EC being $49.7 \%$ in project A. Phase D is insignificant, as there are no PENRM credits for any of the projects. This stems from the fact that the Ökobaudat 2016-I contains very few (a total of 21) building materials receiving a PENRM credit in phase $\mathrm{D}$ and none of them is used in any of the case study projects. When using $\mathrm{ADP}_{\text {elem }}$, life cycle phases A1-A3 contribute between 52 and $82 \%$ of EC, and phase D provides a maximum credit of $6 \%$.

In the context to the ECs calculated in Section 4.1, resource depletion EC is of significant magnitude. If the minimal valuation for all environmental impact indicators is used, EC of resource depletion adds at least $193 \%$ to the minimum EC (project $\mathrm{D}, \mathrm{LC}$ phases $\mathrm{A} 1-\mathrm{A} 3, \mathrm{APD}_{\text {elem }}$ ) and can add up to $2212 \%$ (project F, all LC phases, PENRM). Assuming maximal cost assessment, resource depletion adds between $7.4 \%$ (project $\mathrm{F}$, all $\mathrm{LC}$ phases, $\mathrm{APD}_{\text {elem}}$ ) and $74.6 \%$ to total EC (project F, LC phases A1-A3, C3, C4, D, PENRM).

For a more detailed analysis of the materials causing high values of the resource depletion indicators, we looked at the materials used in project $\mathrm{E}$ and project $\mathrm{F}$. Project $\mathrm{E}$ stands out in its assessment under $\mathrm{ADP}_{\text {elem }}$ and project $\mathrm{F}$ in its assessment under PENRM. The former is also the only project for which $\mathrm{ADP}_{\text {elem }}$ yields higher EC than PENRM, the latter yields the highest values of all projects for PENRM.

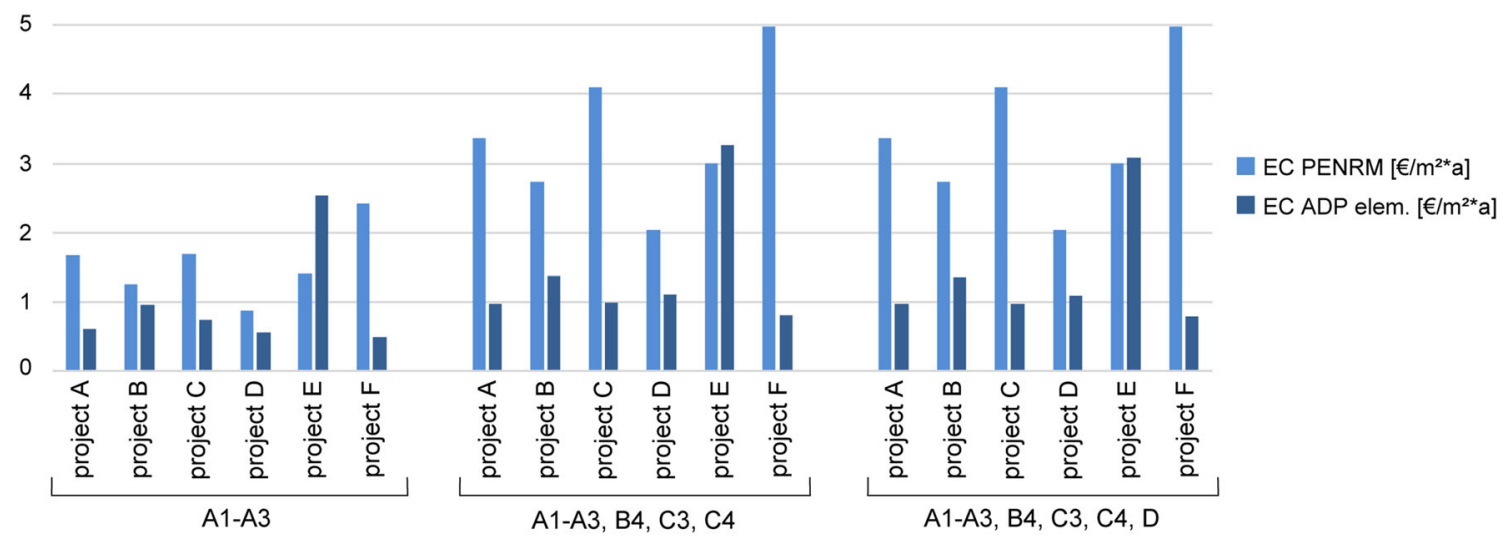

Fig. 7 EC of resource depletion of the case study projects in $€$ per $\mathrm{m}^{2}$ UFA and year; comparison between EC for non-renewable primary energy for material resources (PENRM) and abiotic depletion potential elements (ADPelem.); corresponding numbers are listed in Table 8 
PENRM generates an extraordinarily high portion of project F's EC because of that project's exterior walls, namely, its EPS and XPS insulation and its PVC window frames. These elements have to be exchanged once during the reference study period, almost doubling the EC of the exterior walls. XPS and EPS are also applied in other projects causing high shares of PENRM, as do bituminous materials, but not to the extent as in project F. The high $\mathrm{ADP}_{\text {elem }}$ values for project $\mathrm{E}$, by contrast, can be traced back almost exclusively to the stainless steel enclosure of some of the building's mechanical systems placed on the roof. The fact that this material is used in none of the other projects explains why project $\mathrm{E}$ yields an anomalous (because greater than under PENRM) EC when employing $\mathrm{ADP}_{\text {elem }}$.

\subsection{Relationship between environmental costs and life cycle costs}

Fully internalizing EC into the life cycle costs of buildings allows for a better-informed cost-benefit analysis of more environmentally friendly, but potentially more costly, alternative building designs and construction methods. To see under which circumstances EC may influence such choices, we compared investment costs (costs for phases $\mathrm{A} 1-\mathrm{A} 5)$ to $\mathrm{EC}$ for phases A1-A3, as well as life cycle costs (LCC) for all phases considered in standard LCC calculations to life cycle EC. Phase D is excluded from this comparison, as no cost credit data exist for benefits and loads outside of the system boundary. As phases B2 (maintenance) and B3 (repair) are not accounted for in the LCA calculations (Fig. 2), we show the costs of these phases separately from other phases.

Figure 8 illustrates that EC derived from minimal cost assumptions account for a mere 1.04 to $1.46 \%$ of building construction cost for phases A1-A3 and even less (0.66 to $0.80 \%$ ) if life cycle costs and the full life cycle is considered (phases A to C). EC using maximal cost assumptions, however, is equal to between 26 and $37 \%$ of construction costs, 16 to $20 \%$ of total LCC, and 23 to $34 \%$ to LCC disregarding phases B2 and B3. The difference between EC and LCC increases for the full life cycle, as the use phase (not including energy use for building operation) adds more costs than environmental impacts.

It is evident that EC and LCC are not inversely correlated, i.e., projects with lower EC are not necessarily more expensive. On the contrary, Project F, for instance, shows both low EC for phases A1-A3 and low construction costs. For the full life cycle (excluding B2 and B3), project $\mathrm{F}$ has the secondlowest LCC and the lowest EC. On the other end, project E, with the highest construction and life cycle costs, shows a mid-range EC.

\subsection{Minimizing environmental costs}

Different variations of project $F$ (Table 4) were investigated in order to minimize its EC. As GWP appears to be the preponderant indicator, variation F15 replaces the reinforced concrete structure with a wood structure in order to realize the large GWP dividend implied by this change. In particular, Ökobaudat attributes a GWP credit to wood in phase A1-A3 for carbon storage, allowing project F15 to show negative EC for these phases.

F15 contains approximately 225 metric tons of wood (and equal amounts of concrete for the base plate), compared with approximately 1412 tons of concrete in versions F1-F3, not considering reinforcement. (These variations contain the highest amount of concrete, as their exterior walls are made of this material.) This choice comes without clear trade-offs in terms of the other, non-GWP,
Fig. 8 Comparison of EC and LCC of the sample projects in $€$ per $\mathrm{m}^{2}$ UFA and year; LCC are subdivided into (partial life cycle) costs for maintenance (B2) and repair (B3) and (partial) life cycle costs A1-A3, B4, and C1; corresponding numbers are listed in Table 9

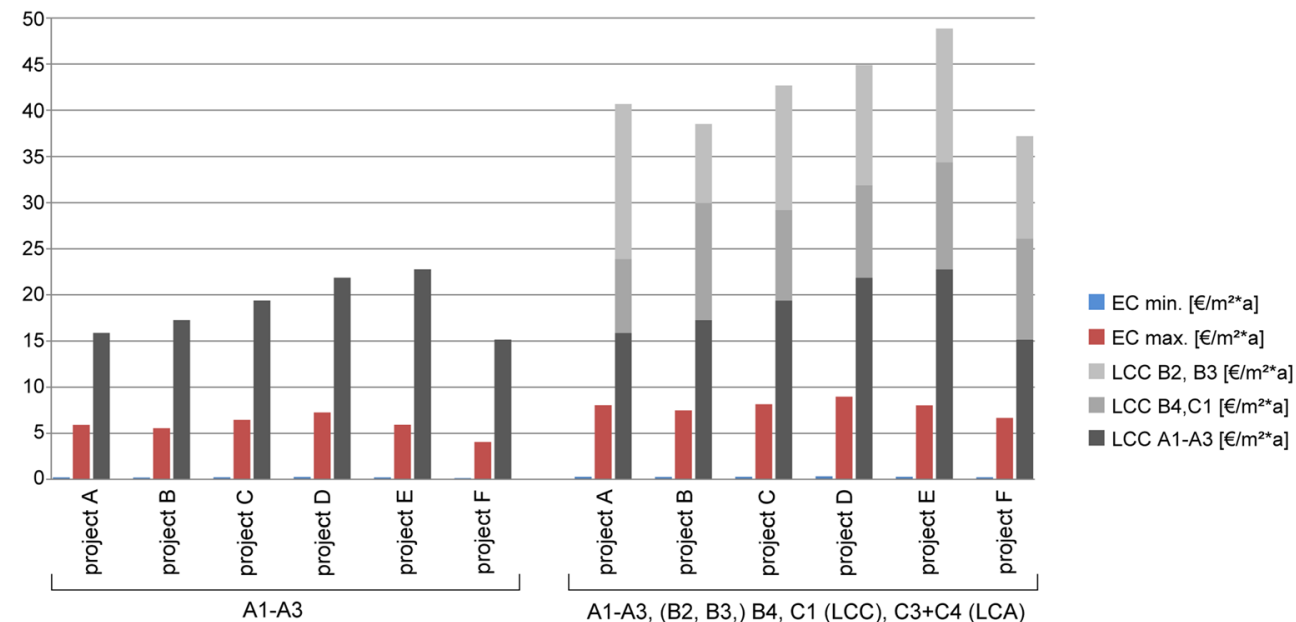


Table 4 Characteristics of variations on project $\mathrm{F}$

\begin{tabular}{llll}
\hline Variation & Structure & Exterior walls & Window frames \\
\hline F1 (project F) & Reinforced concrete & Reinf. concrete + EIFS (185 mm EPS) & PVC \\
F2 & Reinforced concrete & Reinf. concrete + EIFS (185 mm mineral wool) & PVC \\
F3 & Reinforced concrete & Reinf. concrete + EIFS (185 mm EPS, lightweight plaster) & PVC \\
F4 & Reinforced concrete & Masonry + EIFS (65 mm EPS) & PVC \\
F5 & Reinforced concrete & Masonry + EIFS (65 mm mineral wool) & PVC \\
F6 & Reinforced concrete & Masonry + EIFS (65 mm EPS, lightweight plaster) & PVC \\
F7 & Reinforced concrete & Masonry + EIFS (65 mm wood fiber) & PVC \\
F8 & Reinforced concrete & Sand-lime brick + EIFS (190 mm EPS) & PVC \\
F9 & Reinforced concrete & Sand-lime brick + EIFS (190 mm mineral wool) & PVC \\
F10 & Reinforced concrete & Sand-lime brick + EIFS (190 mm EPS, lightweight plaster) & PVC \\
F11 & Reinforced concrete & Wood frame + fiber cement siding & PVC \\
F12 & Reinforced concrete & Wood frame + EIFS (wood fiber) & PVC \\
F13 & Reinforced concrete & Wood frame + ext. plaster (ventilated) & N/A \\
F14 & Reinforced concrete & Aluminum/glass curtain wall & Wood \\
F15 & Wood; & Wood frame + ext. plaster (ventilated) & \\
\hline
\end{tabular}

indicators (Fig. 9). Looking at the underlying indicators, F15 ranks are lowest for both GWP and POCP. While it shows by far the highest values for ODP (7 to 12 times the lowest values) and the second highest values for EP (F14 yields the highest value), these impacts are almost negligible in terms of the overall EC. As a result, F15 emerges as the lowest overall EC option for phases A1 to A3 and full life cycle (including D). Other variations with wood exterior walls (F11 to F13) also substantially reduce EC during these phases.
As wood receives GWP credits for A1-A3, emissions from the end-of life scenario of combustion (for energy generation) are accounted for in phase C3. Therefore, the EC of project $\mathrm{F} 15$ are closer to other variants if the full life cycle without phase D taken into account. It is interesting to see that variant F14 (glazed curtain wall) shows lower EC than the variants with wood exterior walls F11 to F13 for the full life cycle without D. This is due to the end-of-life scenario (recycling) of the curtain wall system.

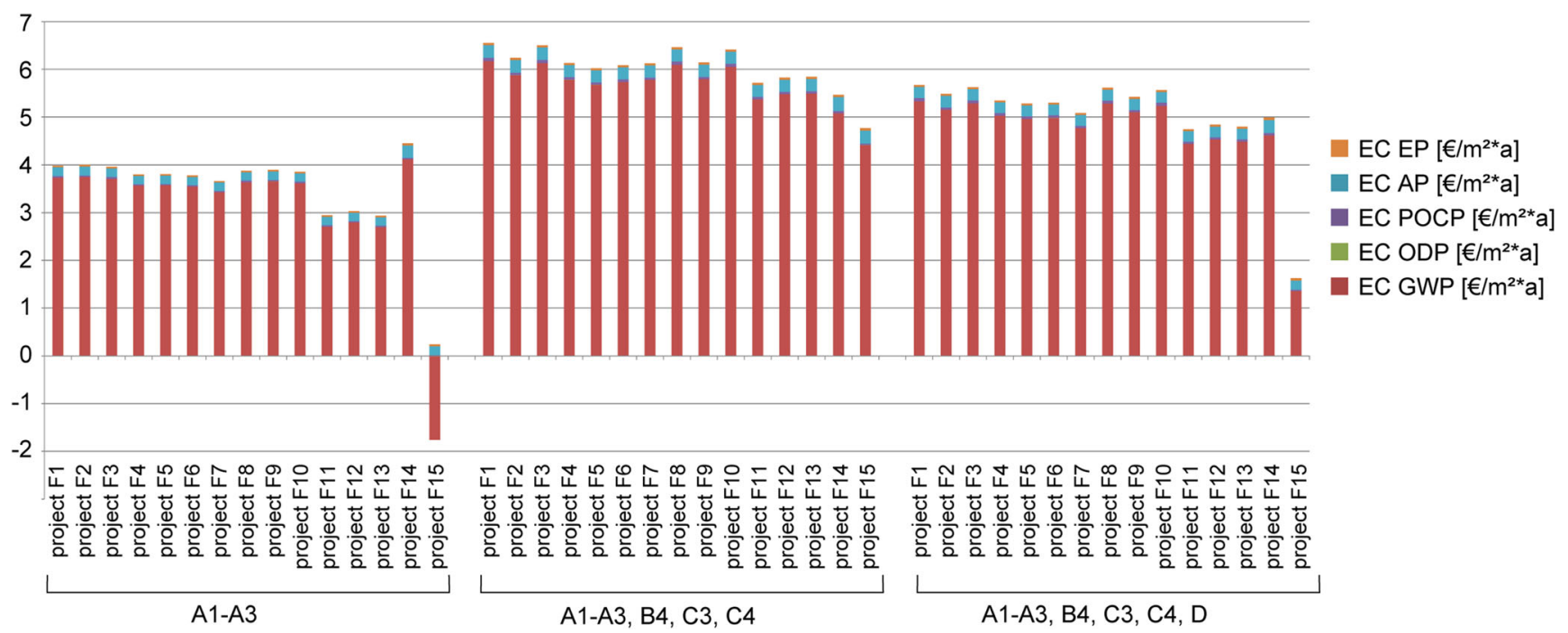

Fig. 9 Total maximum EC in $€$ per $\mathrm{m}^{2}$ and year of different variations of project $\mathrm{F}$; subdivided in EC for eutrophication potential (EP), acidification potential (AP), photochemical creation potential (POCP),

ozone depletion potential (ODP), and global warming potential (GWP); corresponding numbers are listed in Table 10 
The life cycle phases considered impact EC assessments heavily. Generally, wood and other renewable materials are at a disadvantage if phase $\mathrm{D}$ is not taken into account. These materials are in contrast at an advantage if only the production phases A1-A3 are considered. This might change drastically if other databases than Ökobaudat are used, as most databases do not give carbon storage credits to renewable materials. The choice of exterior wall materials influences overall results, but only a change in the structural material makes a significant difference in EC.

\section{Discussion and conclusions}

This study shows that expressing environmental impacts in terms of monetary units has potential for application in the building industry. It offers the opportunity to condense several environmental indicators to one value and hence can help planners and consultants to communicate the results of their investigations of the ecological quality of buildings to clients and stakeholders. Monetary units are easily understood by a layperson and can therefore facilitate including environmental aspects into decision processes. Alternative solutions become comparable in terms of ecological aspects which can also be used in cost-benefit analyses.

Comparing valuation from differing sources and contexts reveals the broad range of actual values assigned to environmental impacts. This cannot be traced back to one particular valuation method, such as damage costs or marginal prevention costs, but appears to be inherent in monetary valuation, as the monetary values of environmental damages and benefits are incomplete and subject to uncertainties. This implies that valuation methods still have gaps and agreed-upon values for emissions are missing. For our study, we used maximum and minimum valuation found in literature in order to determine the resulting range in ecological cost (EC) of buildings and the resulting contribution of each environmental indicator, i.e., the weighting that results from monetary valuation.

The case study of six different construction projects reveals that the contribution of single indicators towards the overall ecological cost (EC) stays consistent, independently of the order of magnitude of the cost assessment. However, the wide variation in terms of assigning monetary values does pose significant challenges to a consistent and generally agreed-upon method for communicating or internalizing EC. The cost values for single mid-point indicators in recent studies differ by a factor of up to thirty-six (photochemical creation potential, POCP), or even range from zero to $30 €$ (ozone depletion potential, ODP). Despite this broad range, of the environmental indicators considered, GWP (attributed to the use of fossil fuels and fossil resources and cement production) has the greatest effect (at least $80 \%$ ) on the overall EC of the buildings considered in the case study. In this, we agree with the previous studies conducted by Adensam et al. (2002) and Ulmer et al. (2010). Acidification potential (AP) with a contribution between 4 and $17 \%$ can tip the scale towards one project over another only if GWP results for the projects to be compared are in close proximity. Otherwise, a ranking of the projects regarding their environmental evaluation according to $\mathrm{EC}$ is identical with a ranking according to GWP. Hence, considering the ranking of projects according to only GWP provides a good approximation for the environmental quality according to the five commonly used indicators (eutrophication potential (EP), acidification potential (AP), photochemical creation potential (POCP), ozone depletion potential (ODP), and global warming potential (GWP)). Acidification potential (AP) can provide additional information if GWP values are similar between projects. For the development of a model for the valuation of environmental costs for embedded impacts for the building industry, GWP and AP are clearly the indicators that should be prioritized.

To put the order of magnitude of potential EC into perspective and evaluate their possible integration into a decision process based on economic factors, we juxtaposed the EC to the LCC of the corresponding life cycle phases. This shows that, even if the highest value recommended for sensitivity analyses is used, internalizing EC into building costs adds no more than $34 \%$ to construction costs. Hence, it is questionable if a low valuation of EC (in fact, tantamount to a low valuation of GWP) will be useful as a basis for decisions in the building industry. In such a case, if the valuation of GWP is at the lower end, the overall EC are low in comparison to LCC: around $1 \%$. For a decision process, this means that the difference in EC between alternative project options could be insignificant compared with a difference in construction and/or life cycle costs. If valuation is at the higher end, integrating EC into project comparison can make a difference. All in all, valuation of environmental costs should be used with caution to avoid the false impression that paying a small additional sum solves all environmental problems related to constructing, using and demolishing buildings: other, unaccounted for externalities exist, and not all of them may be measurable in terms of monetary value. One of these potential factors is toxicity, which could not be considered in this study, as the database used (Ökobaudat) does not provide data for this indicator.

The consideration of resource depletion in the case study suggests that this indicator should be taken into account in building EC assessments as it contributes significantly to overall EC. However, only very few 
methods to assess resource depletion are available. The two methods for doing so that are considered here yield contradictory results. For the valuation of non-renewable primary energy embedded in the material (PENRM), the use of plastics is the most decisive factor. In case of the valuation of abiotic depletion potential (elements) $\left(\mathrm{ADP}_{\text {elem }}\right)$, metals contribute the highest share. This results in the ranking of the case study projects drastically changing depending on the base value (energy input or mid-point) employed. Unlike the valuation of other environmental indicators, the valuation of $\mathrm{ADP}_{\text {elem }}$ can be traced back to one single material used. Notably, this material (stainless steel) could be fairly easily be substituted to lower the valuation for resource depletion. This also points to the fact that excluding materials with a small contribution to the overall mass of the building, e.g., attachment screws, could potentially influence the overall resource consumption disproportionally and might have to be reconsidered. Overall, the fact that the valuation of buildings regarding resource depletion needs to be further investigated is in line with the building industry's high relevance for the consumption of the world's resources.

The evaluation of different variations in the choice of specific materials and components of one sample project indicates the possibility of lowering EC by using woodbased construction materials with low GWP. The dominance of GWP is responsible for the overall EC shrinking without significant trade-offs towards other indicators when a low GWP material is used. But, notably, the end-of-life phases impact the results significantly, as the assessment of different variations of this project change drastically and non-uniformly depending on whether or not these phases are taken into account. This is a direct effect of the accounting for carbon storage in Ökobaudat, providing GWP credits for the product phase, GWP for emissions from combustion in phase $\mathrm{C} 3$, and again GWP credits for the replacement of energy from fossil sources in phase D. Further research is needed to compare the results using other databases such as ecoinvent, ${ }^{6}$ which do not give GWP credits for the carbon storage of wood.

Beyond application of EC in decision processes the question remains if and how EC might be internalized. EC for the product phase (A1-A3) would appear in product pricing, due to environmental taxation or emissions trading. End-of-life costs could only be factored into product prices if producer responsibility can be guaranteed. EC for other life cycle phases (with the exception of the product part of B4) would have to be internalized at the building level.

\footnotetext{
$\overline{6 \text { www.ecoinvent.org }}$
}

This study is limited to embedded environmental impacts and hence excludes energy use during building operation. A separate study of the EC of building operation is needed as previous investigations (Schneider-Marin et al. 2019) show that internalizing EC into the cost of building operation increases operational costs by a significantly higher percentage than internalizing embedded EC into LCC without phase B6. However, if building operation is considered, EC based on the valuation of mid-points-indicators needs to be compared in detail to available EC based on energy sources, i.e., fuel types or renewable sources and electricity mix. In order to gain a complete picture about interdependencies between emissions and energy generation and distribution systems, building services (cost group 400) should also be included.

In this study, office buildings and the materials used in these buildings are considered. Residential or industrial buildings might show different results, but it is unlikely that the overall weighting of indicators would change dramatically, as the bulk of the materials used are comparable. In this context, too, resource depletion has to be carefully considered as single materials can highly influence results.

We conclude that monetary valuation of environmental impacts is a valuable tool for comparisons of different buildings and design options, as they enable LCA practitioners to aggregate results to a single value. Of the indicators considered, GWP proves to have the highest influence on the overall EC of the case study buildings. Therefore, future studies should always consider a range of GWP pricing rather than a single value. The valuation of resource depletion is potentially as influential as GWP valuation and hence requires further research, as to date only few valuation methods are available. The ratio of EC to life cycle costs varies following the magnitude of GWP pricing to such an extent that using EC in project comparison in direct relation to LCC only has a significant influence if GWP pricing is at the higher end of the spectrum.

Acknowledgments Open Access funding provided by Projekt DEAL. The authors would like to thank their colleagues at the Institute of Energy Efficient and Sustainable Design and Building, especially Hannes Harter, Christina Meier-Dotzler, and Christine Röger and their project partners at ATPsustain Munich, Jens Glögger and Klara Meier, for their work on the Design2Eco project, their continuous support, and their availability for discussions. Furthermore, we thank Ferdinand Tausendpfund $\mathrm{GmbH} \& \mathrm{Co}$. KG for providing their office building as a sample project. For their scientific input and valuable feedback, we sincerely thank Dr. Joost Vogtlander and Dr. Leander Schneider. We also thank our anonymous reviewers for their thoughtful comments and efforts towards improving our manuscript.

Funding information Funding for the Design2Eco project and thereby for the LCA and LCC calculations of projects A-E was received from Bundesministerium des Innern, für Bau und Heimat, Germany, under grant number SWD10.08.18.7.-16.60, and from ATP Planungs- und Beteiligungs- AG, BayWa AG, and Stiftung Bayerisches Baugewerbe. 


\section{Appendix 1. External cost studies}

Table 5 Monetary valuation models considered for this study

\begin{tabular}{|c|c|c|c|c|c|}
\hline Method & Year & Emissions/immissions & Mid-points/end-points & $\begin{array}{l}\text { Monetary valuation } \\
\text { method }\end{array}$ & Purpose \\
\hline $\begin{array}{l}\text { ExternE } \\
\text { (Bickel and Friedrich } \\
\text { 2005) }\end{array}$ & $\begin{array}{l}1995, \\
1999 \\
2005\end{array}$ & $\begin{array}{l}\mathrm{PM}_{10}, \mathrm{PM}_{2,5}, \mathrm{SO}_{2}, \mathrm{NO}_{\mathrm{x}}, \mathrm{NMVOC}, \\
\quad \mathrm{NH}_{3}, \mathrm{CO}_{2}, \mathrm{CH}_{4}, \mathrm{~N}_{2} \mathrm{O} \text {, mercury, } \\
\text { noise }\end{array}$ & $\begin{array}{l}\text { Global warming, human health } \\
\text { (morbidity/mortality), building } \\
\text { material, ecosystems, crops, } \\
\text { amenity losses, land use change }\end{array}$ & $\begin{array}{l}\text { Impact Pathway Approach, } \\
\text { WTP to avoid individual } \\
\text { welfare loss }\end{array}$ & Policy making \\
\hline $\begin{array}{l}\text { NewExt } \\
\text { (Rabl et al. 2004) }\end{array}$ & 2004 & $\begin{array}{l}\text { Nitrates, sulfates, } \mathrm{PM}_{10}, \mathrm{SO}_{2}, \\
\text { arsenic, cadmium, chromium, } \\
\text { lead, nickel, formaldehyde }\end{array}$ & $\begin{array}{l}\text { Health impacts, global warming, } \\
\text { damage to buildings and } \\
\text { materials, acidification, } \\
\text { eutrophication }\end{array}$ & $\begin{array}{l}\text { Impact Pathway Approach; } \\
\text { WTP for mortality risk } \\
\text { reductions; revealed } \\
\text { preferences in political } \\
\text { negotiations and public } \\
\text { referenda }\end{array}$ & $\begin{array}{l}\text { Improve ExternE } \\
\text { assessment } \\
\text { system; Policy } \\
\text { making }\end{array}$ \\
\hline $\begin{array}{l}\text { NEEDS } \\
\text { (Preiss et al. 2008) }\end{array}$ & 2009 & 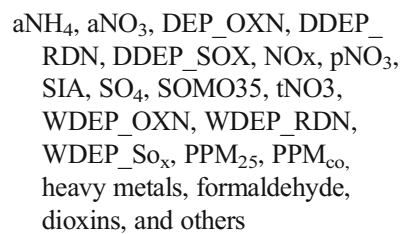 & $\begin{array}{l}\text { Land use changes, acidification, } \\
\text { eutrophication, visual intrusion, } \\
\text { climate change, human health } \\
\text { impact }\end{array}$ & $\begin{array}{l}\text { Impact Pathway Approach; } \\
\text { (based on ExternE, } \\
\text { NewExt) }\end{array}$ & $\begin{array}{l}\text { Policy making: } \\
\text { future electricity } \\
\text { supply }\end{array}$ \\
\hline $\begin{array}{l}\text { CASES (Cost } \\
\text { Assessment for } \\
\text { External Energy } \\
\text { Systems) } \\
\text { (Markandya 2008) }\end{array}$ & 2008 & $\begin{array}{l}\mathrm{CO}_{2}, \mathrm{NH}_{3}, \mathrm{NMVOC} \mathrm{NO}_{\mathrm{X}}, \mathrm{PPM}_{\mathrm{co}} \\
\mathrm{PPM}_{25}, \mathrm{SO}_{2}, \mathrm{Cd}, \mathrm{As}, \mathrm{Ni}, \mathrm{Pb}, \mathrm{Hg} \\
\mathrm{Cr}, \mathrm{CR}-\mathrm{VI}, \text { Formaldehyde, } \\
\text { Dioxin, and others }\end{array}$ & $\begin{array}{l}\text { Environmental damages (human } \\
\text { health, environment, crops), } \\
\text { damage to materials, loss of } \\
\text { biodiversity, climate change }\end{array}$ & $\begin{array}{l}\text { Impact Pathway Approach } \\
\text { (based on ExternE) }\end{array}$ & $\begin{array}{l}\text { Evaluate policy } \\
\text { options }\end{array}$ \\
\hline $\begin{array}{l}\text { LIME (life cycle } \\
\text { impact assessment } \\
\text { method based on } \\
\text { end-point } \\
\text { modeling }\end{array}$ & $\begin{array}{r}\text { Lime-1: } \\
2000 \\
\text { Lime-2: } \\
2006 \\
\text { Lime-3: } \\
2016\end{array}$ & $\begin{array}{l}\mathrm{CO}_{2}, \mathrm{CH}_{4}, \mathrm{~N} 2 \mathrm{O}, \mathrm{HFCs}, \mathrm{PFCs}, \mathrm{SF}_{6}, \\
\text { CFCs Halons, CCI4, 111-TCE, } \\
\mathrm{HCFCs}, \mathrm{CH}_{3} \mathrm{Br} \text {, NMVOCs, } \\
\mathrm{NO}_{\mathrm{X}}, \mathrm{SO}_{2}, \text { Arsenic, Benzene, and } \\
\text { others }\end{array}$ & $\begin{array}{l}\text { Human health, social assets, } \\
\text { biodiversity, primary } \\
\text { production, GWP, ODP, POCP, } \\
\text { urban air pollution, chemical } \\
\text { substances, eco-toxicity, land } \\
\text { use, resource consumption, } \\
\text { waste, land use }\end{array}$ & Conjoint analysis, WTP & $\begin{array}{l}\text { Database for } \\
\text { industry in } \\
\text { Japan, } \\
\text { decision-- } \\
\text { making; } \\
\text { weighting } \\
\text { factors for G20 } \\
\text { countries }\end{array}$ \\
\hline $\begin{array}{l}\text { Virtual Pollution } \\
\text { Prevention costs } 99 \\
\text { (eco-cost) } \\
\text { (Vogtländer 2016) }\end{array}$ & $\begin{array}{l}2000, \\
\text { up- } \\
\text { dated } \\
\text { in } \\
2007,\end{array}$ & & $\begin{array}{l}\text { Human health, eco-toxicity, } \\
\text { resource scarcity, carbon } \\
\text { footprint/GWP, ODP, POCP, } \\
\text { EP, AP, Toxicity }\end{array}$ & Marginal abatement costs & $\begin{array}{l}\text { Application by } \\
\text { designers and } \\
\text { engineers for } \\
\text { decision-- } \\
\text { making }\end{array}$ \\
\hline
\end{tabular}

$\begin{array}{cc} & \text { ent } \\ \text { Ecovalue } 08 / & 2009, \\ \text { Ecovalue } 12 & 2012 \\ \text { (Ahlroth and } & \end{array}$

Finnveden 2011, Finnveden et al. 2013)

Environmental Priority Strategies 1994, (EPS) 1996,

(Steen and Palander 2000, 2016) 2015

Stepwise 2006

(Weidema 2009)
$\mathrm{CO}_{2}, \mathrm{CO}, \mathrm{NO}_{\mathrm{x}}, \mathrm{PM}_{10}, \mathrm{PM}_{2.5}, \mathrm{SO}_{2}$ VOC

Weighting

Damage cost: WTP

\section{estimates/resource depletion: market prices \\ Marinetox, ADP, Particles}
Human health, production capacity of ecosystems, abiotic stock resources

Hunan resource use, eco-toxicity,
human toxicity, GWP, OD human toxicity, GWP, ODP,
POCP; AP, EP (aquatic, terrestrial), and others

Accidents, air pollution, climate change, noise, congestion, well-to-tank emissions, habitat damage, soil and water pollution, and others 
Table 5 (continued)

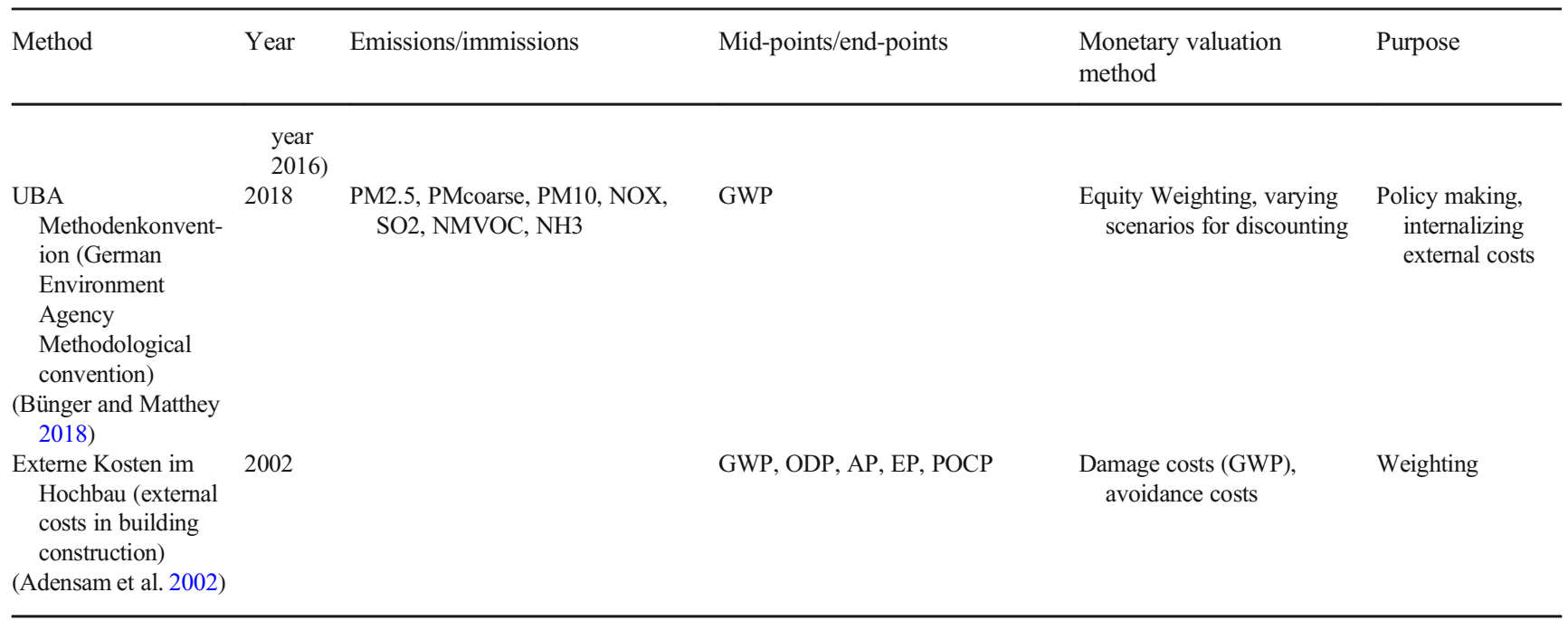

\section{Appendix 2. Case study results}

Table 6 Minimum EC of the case study projects in $€$ per $\mathrm{m}^{2}$ UFA and year

\begin{tabular}{|c|c|c|c|c|c|c|c|c|c|c|}
\hline & & $\begin{array}{l}\text { EC GWP } \\
\left(€ / \mathbf{m}^{2 *} \mathbf{a}\right)\end{array}$ & $\begin{array}{l}\text { EC ODP } \\
\left(€ / \mathbf{m}^{2 *} a\right)\end{array}$ & & $\begin{array}{l}\text { EC POCP } \\
\left(€ / \mathbf{m}^{2 *} \mathbf{a}\right)\end{array}$ & $\begin{array}{l}\text { EC AP } \\
\left(€ / \mathbf{m}^{2 *} \mathbf{a}\right)\end{array}$ & $\begin{array}{l}\text { EC EP } \\
\left(€ / \mathbf{m}^{2 *} \mathbf{a}\right) \\
\end{array}$ & $\begin{array}{l}\text { EC PENRM } \\
\left(€ / \mathbf{m}^{2 *} \mathbf{a}\right)\end{array}$ & $\begin{array}{l}\text { EC ADP } \\
\text { elem. } \\
\left(\epsilon / \mathbf{m}^{2 *} \mathbf{a}\right)\end{array}$ & \begin{tabular}{|l} 
TOTAL EC \\
$($ no RD) \\
$\left(€ / \mathbf{m}^{2 *} \mathbf{a}\right)$
\end{tabular} \\
\hline \multirow{6}{*}{$\mathrm{A} 1-\mathrm{A} 3$} & project A & 0.195606919 & & 0 & 0.000932385 & 0.032815977 & 0.004009904 & 1.642078884 & 0.616715971 & 0.233365184 \\
\hline & project B & 0.18313109 & & 0 & 0.000880171 & 0.034571644 & 0.004273385 & 1.237144934 & 0.964171437 & 0.22285629 \\
\hline & project C & 0.213050631 & & 0 & 0.000692349 & 0.039532373 & 0.004661715 & 1.666446795 & 0.753739856 & 0.257937068 \\
\hline & project D & 0.237997601 & & 0 & 0.000716518 & 0.051494105 & 0.005293717 & 0.868116731 & 0.565758828 & 0.29550194 \\
\hline & project $\mathrm{E}$ & 0.193922637 & & 0 & 0.000586688 & 0.04274227 & 0.004570102 & 1.388988864 & 2.537043469 & 0.241821698 \\
\hline & project $\mathrm{F}$ & 0.134060623 & & 0 & 0.001064958 & 0.021695103 & 0.002808995 & 2.379751839 & 0.494482861 & 0.159629679 \\
\hline \multirow{6}{*}{ A-C } & project A & 0.267098845 & & 0 & 0.00152349 & 0.043784181 & 0.005276027 & 3.303665353 & 0.979454268 & 0.317682543 \\
\hline & project B & 0.246655057 & & 0 & 0.001367528 & 0.045511065 & 0.005846444 & 2.69231178 & 1.373062777 & 0.299380094 \\
\hline & project $\mathrm{C}$ & 0.269438845 & & 0 & 0.000995906 & 0.048867215 & 0.006066463 & 4.02858496 & 0.989891142 & 0.325368429 \\
\hline & project D & 0.29382691 & & 0 & 0.000941994 & 0.062571863 & 0.006958049 & 2.006960504 & 1.106903876 & 0.364298817 \\
\hline & project $\mathrm{E}$ & 0.263383825 & & 0 & 0.000849893 & 0.055711638 & 0.00627434 & 2.949461107 & 3.271993124 & 0.326219695 \\
\hline & project $F$ & 0.221835667 & & 0 & 0.001944721 & 0.031269264 & 0.004014567 & 4.882947689 & 0.805222449 & 0.259064219 \\
\hline \multirow{6}{*}{ A-C-D } & project A & 0.236247235 & & 0 & 0.001438082 & 0.039023579 & 0.00475486 & 3.303665353 & 0.973935095 & 0.281463756 \\
\hline & project B & 0.209746033 & & 0 & 0.001228539 & 0.038306128 & 0.005170153 & 2.69231178 & 1.368275712 & 0.254450853 \\
\hline & project $\mathrm{C}$ & 0.226848994 & & 0 & 0.000873651 & 0.038091328 & 0.005233667 & 4.02858496 & 0.977656763 & 0.271047641 \\
\hline & project D & 0.226851236 & & 0 & 0.000728868 & 0.04330286 & 0.005582914 & 2.006960504 & 1.090033482 & 0.276465878 \\
\hline & project $\mathrm{E}$ & 0.223237331 & & 0 & 0.000714006 & 0.044812409 & 0.00548121 & 2.949461107 & 3.084380001 & 0.274244955 \\
\hline & project $\mathrm{F}$ & 0.191474394 & & 0 & 0.001892622 & 0.02779115 & 0.003578641 & 4.882947689 & 0.792618928 & 0.224736806 \\
\hline
\end{tabular}


Table 7 Maximum EC of the case studies in $€$ per $\mathrm{m}^{2}$ UFA and year

\begin{tabular}{|c|c|c|c|c|c|c|c|c|c|c|}
\hline & & $\begin{array}{l}\text { EC GWP } \\
\left(€ / \mathbf{m}^{2 *} \mathbf{a}\right)\end{array}$ & $\begin{array}{l}\text { EC ODP } \\
\left(€ / \mathbf{m}^{2 *} \mathbf{a}\right)\end{array}$ & $\begin{array}{l}\text { EC РОCP } \\
\left(€ / \mathbf{m}^{2 *} \mathbf{a}\right)\end{array}$ & $\begin{array}{l}\text { EC AP } \\
\left(€ / \mathbf{m}^{2 *} \mathbf{a}\right)\end{array}$ & $\begin{array}{l}\text { EC EP } \\
\left(€ / \mathbf{m}^{2 *} \mathbf{a}\right)\end{array}$ & $\begin{array}{l}\text { EC PENRM } \\
\left(\epsilon / \mathbf{m}^{2 *} \mathbf{a}\right)\end{array}$ & $\begin{array}{l}\text { EC ADP } \\
\text { elem. } \\
\left(€ / \mathbf{m}^{2 *} \mathbf{a}\right)\end{array}$ & \begin{tabular}{|l} 
TOTAL EC \\
$($ no RD) \\
$\left(\mathbf{E} / \mathbf{m}^{2 *} \mathbf{a}\right)$ \\
\end{tabular} & $\begin{array}{l}\text { factor EC } \\
\text { min. }\end{array}$ \\
\hline \multirow{6}{*}{ A1-A3 } & project A & 5.54503092 & $3.94605 \mathrm{E}-07$ & 0.033727412 & 0.278843101 & 0.041721022 & 1.642078884 & 0.616715971 & 5.89932285 & 25 \\
\hline & project B & 5.191368298 & $6.23783 \mathrm{E}-07$ & 0.031838671 & 0.293761315 & 0.044462408 & 1.237144934 & 0.964171437 & 5.561431315 & 25 \\
\hline & project $\mathrm{C}$ & 6.039522247 & $6.38666 \mathrm{E}-07$ & 0.025044528 & 0.335913497 & 0.048502783 & 1.666446795 & 0.753739856 & 6.448983693 & 25 \\
\hline & project D & 6.746714588 & 4.92016E-07 & 0.025918806 & 0.437554429 & 0.055078449 & 0.868116731 & 0.565758828 & 7.265266764 & 25 \\
\hline & project $\mathrm{E}$ & 5.4972852 & 4.75413E-07 & 0.02122245 & 0.363188558 & 0.047549598 & 1.388988864 & 2.537043469 & 5.929246281 & 25 \\
\hline & project $\mathrm{F}$ & 3.800327227 & $5.04344 \mathrm{E}-07$ & 0.038523032 & 0.184347086 & 0.029226173 & 2.379751839 & 0.494482861 & 4.052424022 & 25 \\
\hline \multirow{6}{*}{ A-C } & project A & 7.571671603 & 4.98011E-07 & 0.055109642 & 0.372041855 & 0.054894396 & 3.303665353 & 0.979454268 & 8.053717993 & 25 \\
\hline & project B & 6.99213465 & 7.8846E-07 & 0.049467976 & 0.386715489 & 0.060829296 & 2.69231178 & 1.373062777 & 7.4891482 & 25 \\
\hline & project C & 7.638005528 & 8.96975E-07 & 0.036025187 & 0.415233284 & 0.063118475 & 4.02858496 & 0.989891142 & 8.152383372 & 25 \\
\hline & project D & 8.329354152 & $6.72988 \mathrm{E}-07$ & 0.034075026 & 0.531684078 & 0.072394984 & 2.006960504 & 1.106903876 & 8.967508914 & 25 \\
\hline & project $\mathrm{E}$ & 7.466358854 & $6.05169 \mathrm{E}-07$ & 0.030743413 & 0.473391543 & 0.065281338 & 2.949461107 & 3.271993124 & 8.035775754 & 25 \\
\hline & project $F$ & 6.288558899 & $6.07282 \mathrm{E}-07$ & 0.070346954 & 0.26570041 & 0.041769543 & 4.882947689 & 0.805222449 & 6.666376413 & 26 \\
\hline \multirow{6}{*}{ A-C-D } & project A & 6.697095526 & $3.15802 \mathrm{E}-07$ & 0.052020168 & 0.331590186 & 0.049471914 & 3.303665353 & 0.973935095 & 7.13017811 & 25 \\
\hline & project B & 5.945844061 & $6.04712 \mathrm{E}-07$ & 0.044440283 & 0.325493879 & 0.053792831 & 2.69231178 & 1.368275712 & 6.369571659 & 25 \\
\hline & project $\mathrm{C}$ & 6.43067584 & $8.22749 \mathrm{E}-07$ & 0.031602842 & 0.323668683 & 0.05445366 & 4.02858496 & 0.977656763 & 6.840401847 & 25 \\
\hline & project D & 6.430739387 & $4.27801 \mathrm{E}-07$ & 0.026365551 & 0.367951987 & 0.058087393 & 2.006960504 & 1.090033482 & 6.883144745 & 25 \\
\hline & project $\mathrm{E}$ & 6.328293027 & $3.96736 \mathrm{E}-07$ & 0.025827948 & 0.380778885 & 0.057029214 & 2.949461107 & 3.084380001 & 6.791929471 & 25 \\
\hline & project $\mathrm{F}$ & 5.427882811 & $3.84347 \mathrm{E}-07$ & 0.068462347 & 0.23614627 & 0.037233945 & 4.882947689 & 0.792618928 & 5.769725757 & 26 \\
\hline
\end{tabular}

Table 8 EC of resource depletion

\begin{tabular}{llll}
\hline & & EC PENRM $\left(€ / \mathrm{m}^{2 * a}\right)$ & EC ADP elem. $\left(€ / \mathrm{m}^{2 * a}\right)$ \\
\hline A1-A3 & Project A & 1.64207888 & 0.61671597 \\
& Project B & 1.23714493 & 0.96417144 \\
& Project C & 1.66644679 & 0.75373986 \\
& Project D & 0.86811673 & 0.56575883 \\
& Project E & 1.38898886 & 2.53704347 \\
& Project F & 2.37975184 & 0.49448286 \\
A-C & Project A & 3.30366535 & 0.97945427 \\
& Project B & 2.69231178 & 1.37306278 \\
& Project C & 4.02858496 & 0.98989114 \\
& Project D & 2.0069605 & 1.10690388 \\
& Project E & 2.94946111 & 3.27199312 \\
& Project F & 4.88294769 & 0.80522245 \\
A-C-D & Project A & 3.30366535 & 0.97393509 \\
& Project B & 2.69231178 & 1.36827571 \\
& Project C & 4.02858496 & 0.97765676 \\
& Project D & 2.0069605 & 1.09003348 \\
& Project E & 2.94946111 & 3.08438 \\
Project F & 4.88294769 & 0.79261893 \\
\hline
\end{tabular}


Table 9 Comparison of EC and LCC of the sample projects

\begin{tabular}{|c|c|c|c|c|}
\hline EC $\min .\left(€ / \mathrm{m}^{2} * \mathrm{a}\right)$ & EC max. $\left(€ / \mathrm{m}^{2} * a\right)$ & $\begin{array}{l}\mathrm{LCC} \\
\left(€ / \mathrm{m}^{2} * \mathrm{a}\right)\end{array}$ & $\mathrm{EC} \mathrm{min} / \mathrm{LCC}(\%)$ & $\mathrm{EC} \mathrm{max} / \mathrm{LCC}(\%)$ \\
\hline
\end{tabular}

\begin{tabular}{|c|c|c|c|c|c|c|}
\hline \multirow[t]{6}{*}{ A1-A3 } & Project A & 0.23 & 5.90 & 15.88 & 1.47 & 37 \\
\hline & Project B & 0.22 & 5.56 & 17.24 & 1.29 & 32 \\
\hline & Project C & 0.26 & 6.45 & 19.36 & 1.33 & 33 \\
\hline & Project D & 0.30 & 7.27 & 21.85 & 1.35 & 33 \\
\hline & Project E & 0.24 & 5.93 & 22.75 & 1.06 & 26 \\
\hline & Project F & 0.16 & 4.05 & 15.18 & 1.05 & 27 \\
\hline \multirow{6}{*}{$\begin{array}{l}\text { A1-A3, } \\
\text { B4, } \\
\text { C1, C3, C4 }\end{array}$} & Project A & 0.32 & 8.05 & 40.65 & 0.78 & 20 \\
\hline & Project B & 0.30 & 7.49 & 38.52 & 0.78 & 19 \\
\hline & Project C & 0.33 & 8.15 & 42.67 & 0.76 & 19 \\
\hline & Project D & 0.36 & 8.97 & 44.88 & 0.81 & 20 \\
\hline & Project E & 0.33 & 8.04 & 48.84 & 0.67 & 16 \\
\hline & Project F & 0.26 & 6.67 & 37.22 & 0.70 & 18 \\
\hline \multirow{6}{*}{$\begin{array}{l}\text { A1-A3, } \\
\text { B2, B3, B4, } \\
\text { C1, C3, C4 }\end{array}$} & Project A & 0.32 & 8.05 & 23.87 & 1.33 & 34 \\
\hline & Project B & 0.30 & 7.49 & 29.95 & 1.00 & 25 \\
\hline & Project C & 0.33 & 8.15 & 29.19 & 1.11 & 28 \\
\hline & Project D & 0.36 & 8.97 & 31.89 & 1.14 & 28 \\
\hline & Project E & 0.33 & 8.04 & 34.37 & 0.95 & 23 \\
\hline & Project $F$ & 0.26 & 6.67 & 26.10 & 0.99 & 26 \\
\hline
\end{tabular}


Table 10 Maximum EC in $€$ per $\mathrm{m}^{2}$ and year of different variations of project $\mathrm{F}$

\begin{tabular}{|c|c|c|c|c|c|c|c|}
\hline & & $\begin{array}{l}\text { EC GWP } \\
\left(€ / \mathbf{m}^{2 *} \mathbf{a}\right) \\
\end{array}$ & $\begin{array}{l}\text { EC ODP } \\
\left(€ / \mathbf{m}^{2 *} \mathbf{a}\right) \\
\end{array}$ & $\begin{array}{l}\text { EC POCP } \\
\left(€ / \mathbf{m}^{2 * a}\right) \\
\end{array}$ & $\begin{array}{l}\text { EC AP } \\
\left(€ / \mathbf{m}^{2 *} \mathbf{a}\right) \\
\end{array}$ & $\begin{array}{l}\text { EC EP } \\
\left(€ / \mathbf{m}^{2 * a} \mathbf{a}\right) \\
\end{array}$ & \begin{tabular}{|l} 
TOTAL EC \\
$($ no RD) \\
$\left(€ / \mathbf{m}^{2 * a}\right)$ \\
\end{tabular} \\
\hline \multirow{15}{*}{ A1-A3 } & project F1 & 3.80 & 0.00 & 0.04 & 0.18 & 0.03 & 4.052424022 \\
\hline & project F2 & 3.82 & 0.00 & 0.03 & 0.19 & 0.03 & 4.071260832 \\
\hline & project F3 & 3.78 & 0.00 & 0.04 & 0.18 & 0.03 & 4.028932364 \\
\hline & project F4 & 3.63 & 0.00 & 0.03 & 0.17 & 0.03 & 3.867838856 \\
\hline & project F5 & 3.64 & 0.00 & 0.03 & 0.18 & 0.03 & 3.874457194 \\
\hline & project F6 & 3.61 & 0.00 & 0.03 & 0.17 & 0.03 & 3.844347198 \\
\hline & project F7 & 3.49 & 0.00 & 0.03 & 0.18 & 0.03 & 3.725837893 \\
\hline & project F8 & 3.71 & 0.00 & 0.04 & 0.17 & 0.03 & 3.944608877 \\
\hline & project F9 & 3.73 & 0.00 & 0.03 & 0.18 & 0.03 & 3.96395479 \\
\hline & project F10 & 3.69 & 0.00 & 0.04 & 0.17 & 0.03 & 3.921117219 \\
\hline & project F11 & 2.76 & 0.00 & 0.03 & 0.18 & 0.03 & 2.993140568 \\
\hline & project F12 & 2.85 & 0.00 & 0.03 & 0.17 & 0.03 & 3.079664056 \\
\hline & project F13 & 2.75 & 0.00 & 0.03 & 0.18 & 0.03 & 2.984590514 \\
\hline & project F14 & 4.20 & 0.00 & 0.03 & 0.26 & 0.04 & 4.526435149 \\
\hline & project F15 & -1.80 & 0.00 & 0.02 & 0.18 & 0.04 & -1.55437006 \\
\hline \multirow{15}{*}{ A-C } & project F1 & 6.29 & 0.00 & 0.07 & 0.27 & 0.04 & 6.666376413 \\
\hline & project F2 & 5.99 & 0.00 & 0.05 & 0.27 & 0.04 & 6.349568401 \\
\hline & project F3 & 6.24 & 0.00 & 0.07 & 0.26 & 0.04 & 6.617518835 \\
\hline & project F4 & 5.89 & 0.00 & 0.06 & 0.25 & 0.04 & 6.237443781 \\
\hline & project F5 & 5.78 & 0.00 & 0.05 & 0.25 & 0.04 & 6.126132858 \\
\hline & project F6 & 5.84 & 0.00 & 0.06 & 0.25 & 0.04 & 6.188586204 \\
\hline & project F7 & 5.89 & 0.00 & 0.05 & 0.26 & 0.04 & 6.230801616 \\
\hline & project F8 & 6.21 & 0.00 & 0.07 & 0.25 & 0.04 & 6.573776865 \\
\hline & project F9 & 5.90 & 0.00 & 0.05 & 0.26 & 0.04 & 6.248406475 \\
\hline & project $\mathrm{F} 10$ & 6.16 & 0.00 & 0.07 & 0.25 & 0.04 & 6.524919287 \\
\hline & project F11 & 5.47 & 0.00 & 0.05 & 0.25 & 0.04 & 5.812615347 \\
\hline & project F12 & 5.58 & 0.00 & 0.05 & 0.25 & 0.04 & 5.923534476 \\
\hline & project F13 & 5.59 & 0.00 & 0.05 & 0.26 & 0.04 & 5.942727456 \\
\hline & project F14 & 5.17 & 0.00 & 0.05 & 0.29 & 0.04 & 5.557025438 \\
\hline & project F15 & 4.50 & 0.00 & 0.03 & 0.27 & 0.05 & 4.853048456 \\
\hline \multirow{15}{*}{ A-C-D } & project F1 & 5.43 & 0.00 & 0.07 & 0.24 & 0.04 & 5.769725757 \\
\hline & project F2 & 5.25 & 0.00 & 0.05 & 0.24 & 0.04 & 5.578573231 \\
\hline & project F3 & 5.38 & 0.00 & 0.07 & 0.23 & 0.04 & 5.720868179 \\
\hline & project F4 & 5.12 & 0.00 & 0.05 & 0.23 & 0.04 & 5.439103757 \\
\hline & project F5 & 5.06 & 0.00 & 0.05 & 0.23 & 0.04 & 5.371942059 \\
\hline & project F6 & 5.08 & 0.00 & 0.05 & 0.22 & 0.03 & 5.39024618 \\
\hline & project F7 & 4.86 & 0.00 & 0.05 & 0.22 & 0.04 & 5.17038759 \\
\hline & project F8 & 5.38 & 0.00 & 0.07 & 0.23 & 0.04 & 5.709213519 \\
\hline & project F9 & 5.20 & 0.00 & 0.05 & 0.23 & 0.04 & 5.512894709 \\
\hline & project F10 & 5.33 & 0.00 & 0.07 & 0.22 & 0.04 & 5.660355942 \\
\hline & project F11 & 4.53 & 0.00 & 0.05 & 0.22 & 0.04 & 4.831936248 \\
\hline & project F12 & 4.62 & 0.00 & 0.05 & 0.22 & 0.04 & 4.926971668 \\
\hline & project F13 & 4.57 & 0.00 & 0.05 & 0.22 & 0.04 & 4.88549255 \\
\hline & project F14 & 4.71 & 0.00 & 0.05 & 0.27 & 0.04 & 5.071394712 \\
\hline & project F15 & 1.38 & 0.00 & 0.03 & 0.19 & 0.05 & 1.646770489 \\
\hline
\end{tabular}


Open Access This article is licensed under a Creative Commons Attribution 4.0 International License, which permits use, sharing, adaptation, distribution and reproduction in any medium or format, as long as you give appropriate credit to the original author(s) and the source, provide a link to the Creative Commons licence, and indicate if changes were made. The images or other third party material in this article are included in the article's Creative Commons licence, unless indicated otherwise in a credit line to the material. If material is not included in the article's Creative Commons licence and your intended use is not permitted by statutory regulation or exceeds the permitted use, you will need to obtain permission directly from the copyright holder. To view a copy of this licence, visit http://creativecommons.org/licenses/by/4.0/.

\section{References}

Adensam H, Bruck M, Geissler S, Fellner M (2002) Externe Kosten. Externe Kosten im Hochbau. Band I, Wien

Ahbe S (2014) Methode der ökologischen Knappheit für Deutschland. Umweltbewertungen in Unternehmen ; eine Initiative der Volkswagen AG, 2., überarb. Aufl. AutoUni-Schriftenreihe, vol 68. Logos-Verl., Berlin

Ahlroth S (2009) Valuation of environmental impacts and its use in environmental systems analysis tools. PhD Dissertation, Royal institute of Technology

Ahlroth S, Finnveden G (2011) Ecovalue08-a new valuation set for environmental systems analysis tools. J Clean Prod 19(17-18):1994 2003. https://doi.org/10.1016/j.jclepro.2011.06.005

Ahlroth S, Nilsson M, Finnveden G, Hjelm O, Hochschorner E (2011) Weighting and valuation in selected environmental systems analysis tools - suggestions for further developments. J Clean Prod 19(2-3): 145-156. https://doi.org/10.1016/j.jclepro.2010.04.016

atmosfair gGmbH (2019) FAQs Zur $\mathrm{CO}_{2}$-Berechnung. https://www. atmosfair.de/de/faqs/zur_co $\%$ E2\%82\%82-berechnung/. Accessed 18 Nov 2019

Bengtsson M, Steen B (2000) Weighting in LCA - approaches and applications. Environ Prog 19(2):101-109

Bickel P, Friedrich R (2005) ExternE. Externalities of energy - methodology 2005 update. Sustainable energy systems, vol 21951. Office for Official Publications of the European Communities, Luxembourg

BMU (2019) Klimaschutzprogramm 2030 der Bundesregierung zur Umsetzung des Klimaschutzplans 2050

British Standards Institution (2011) BS EN 15978 Sustainability of construction works. Assessment of environmental performance of buildings. Calculation method

Building Quality Foundation (Stichting Bouwkwaliteit) (2019) Determination method environmental performance buildings and civil engineering works. Determination method for determining the environmental performance of buildings and civil engineering works over their entire service life, based on EN 15804. Version 3.0, Rijswijk

Bundesinstitut für Bau-, Stadt- und Raumforschung (BBSR) im Bundesamt für Bauwesen und Raumentwicklung (BBR) (2011) Nutzungsdauern von Bauteilen für Lebenszyklusanalysen nach Bewertungssystem Nachhaltiges Bauen (BNB)

Bundesministerium des Innern, für Bau und Heimat (BMI) (2016) Ökobaudat. www.oekobaudat.de. Accessed 4 Jan 2020

Bünger B, Matthey A (2018) Methodenkonvention 3.0 zur Ermittlung von Umweltkosten. Methodische Grundlagen, Dessau-Roßlau

Deutsches Institut für Normung e.V (2008) DIN 276-1 Kosten im Bauwesen. Teil 1: Hochbau (DIN 276-1:2008-12)

DGNB GmbH (2018) ENV1.1 Oekobilanz des Gebaeudes. DGNB system - Kriterienkatalog Gebäude Neubau

DIN Deutsches Institut für Normung e.V (2009) DIN EN ISO 14040 Environmental management - life cycle assessment - principles and framework. (ISO 14040:2006); German and English version EN ISO 14040:2006(DIN EN ISO 14040:2009-11). https://doi. org/10.31030/1555059. Accessed 06 Nov 2019
DIN Deutsches Institut für Normung e.V (2012) DIN EN 15978 Nachhaltigkeit von Bauwerken - Bewertung der umweltbezogenen Qualität von Gebäuden - Berechnungsmethode;. Deutsche Fassung EN 15978:2011(DIN EN 15978:2012-10). https://doi.org/10. 31030/1917049. Accessed 06 Nov 2019

DIN Deutsches Institut für Normung e.V (2014) DIN EN 15804 Nachhaltigkeit von Bauwerken - Umweltproduktdeklarationen Grundregeln für die Produktkategorie Bauprodukte;. Deutsche Fassung EN 15804:2012 + A1:2013(DIN EN 15804:2014-0). https://doi.org/10.31030/2074465. Accessed 06 Nov 2019

European Commission (2014) Carbon leakage list 2015 to 2019. Official Journal of the European Union(L 308):114-124

European Commission (2020) Allocation to industrial installations. https://ec.europa.eu/clima/policies/ets/allowances/industrial_en. Accessed 05 Mar 2020

Finnveden G, Eldh P, Johansson J (2006) Weighting in LCA based on ecotaxes development of a mid-point method and experiences from case studies. Int J LCA 11(S1):81-88. https://doi.org/10.1065/lca2006.04.015

Finnveden G, Håkansson C, Noring M (2013) A new set of evaluation factors for LCA and LCC based on damage costs - EcoValue 2012. In: The 6th International Conference on Life Cycle Management in Gothenburg 2013

Freeman AM, Burtraw D, Harrington W, Krupnick AJ (1992) Weighing environmental externalities: how to do it right. Electr J 5(7):18-25. https://doi.org/10.1016/1040-6190(92)90181-6

Friedrich R, Rabl A, Spadaro JV (2001) Quantifying the costs of air pollution: the ExternE project of the EC. Pollut Atmos:77-104

Friedrich R, Bickel P, Greßmann A, Droste-Franke B, Renn O, Maibach M, Thöne M (2007) Ökonomische Bewertung von Umweltschäden. Methodenkonvention zur Schätzung externer Umweltkosten

Giljum S, Burger E, Hinterberger F, Lutter S, Bruckner M (2011) A comprehensive set of resource use indicators from the micro to the macro level. Resour Conserv Recycl 55(3):300-308. https://doi.org/ 10.1016/j.resconrec.2010.09.009

Goedkoop M, Heijungs R, Huijbregts M, de Schryver A, Struijs J, van Zelm R (2013) ReCiPe 2008. A life cycle impact assessment method which comprises harmonised category indicators at the midpoint and the endpoint level. Report I: Characterisation, First edition (version 1.08)

Hegger M, Fuchs M, Stark T, Zeumer M (2012) Energie Atlas, Nachhaltige Architektur. Birkhäuser, Berlin, Basel

Hellweg S, Hofstetter TB, Hungerbühler K (2003) Discounting and the environment should current impacts be weighted differently than impacts harming future generations? Int J Life Cycle Assessment 8. https://doi.org/10.1007/BF02978744

IBO - Österreichisches Institut für Bauen und Ökologie GmbH (2016) OI3-Indikator. Leitfaden zur Berechnung von Ökokennzahlen für Gebäude. Version 3.1, Wien

International Emergy Agency (IEA) (2018) 2018 Global Status Report: towards a zero-emission, efficient and resilient buildings and construction sector

International Organization for Standardization (2019) ISO 14008 Monetary valuation of environmental impacts and related envioronmental aspects (ISO 14008:2019)

Kägi T, Dinkel F, Frischknecht R, Humbert S, Lindberg J, de Mester S, Ponsioen T, Sala S, Schenker UW (2016) Session "Midpoint, endpoint or single score for decision-making?". SETAC Europe 25th Annual Meeting, May 5th, 2015. Int J Life Cycle Assess 21:129-132

Klaassens E (2014) Resource Efficiency in the Building Sector

Klinglmair M, Sala S, Brandão M (2014) Assessing resource depletion in LCA. A review of methods and methodological issues. Int J Life Cycle Assess 19(3):580-592. https://doi.org/10.1007/s11367-013-0650-9

Klöpffer W, Grahl B (2009) Ökobilanz (LCA). Ein Leitfaden für Ausbildung und Beruf. Wiley-VCH, Weinheim

Mahler P, Schneider P (2017) The influence of databases on the life cycle assessment (LCA) of building components - a comparison of databases using three different wall constructions. In: Bakker J, Frangopol DM, van Breugel K (eds) Life-cycle of engineering 
systems: emphasis on sustainable infrastructure. Proceedings of the Fifth International Syposium on Life-Cycle Engineering Systems, London, pp 967-974

Markandya A (2008) CASES cost assessment of sustainable energy systems. Development of a set of full cost estimates of the use of different energy sources and its comparative assessment in EU countries. Project No 518294 SES6 Deliverable D 6.1 Part 2 Full Cost: Levelised European Esstiamtes Results and Assessment

Matthey A, Bünger B (2019) Methodenkonvention 3.0 zur Ermittlung von Umweltkosten. Kostensätze. Stand 02 / 2019, Dessau-Roßlau

Mishra SK (2006) Valuation of environmental goods and services. In: Singh OP (ed) Environment and natural resources: ecological and economic perspectives. Regency Publications, New Delhi, pp 34-54

Murakami K, Itsubo N, Kuriyama K, Yoshida K, Tokimatsu K (2018) Development of weighting factors for G20 countries. Part 2: estimation of willingness to pay and annual global damage cost. Int J Life Cycle Assess 23(12):2349-2364. https://doi.org/10.1007/s11367017-1372-1

OECD (2019) Price level indices (indicator) // Prices. https://data.oecd. org/price/price-level-indices.htm\#indicator-chart. Accessed 25 Nov 2019

Pizzol M, Weidema B, Brandão M, Osset P (2015) Monetary valuation in life cycle assessment: a review. J Clean Prod 86:170-179. https:// doi.org/10.1016/j.jclepro.2014.08.007

Pizzol M, Laurent A, Sala S, Weidema B, Verones F, Koffler C (2017) Normalisation and weighting in life cycle assessment: quo vadis? Int J Life Cycle Assess 22(6):853-866. https://doi.org/10.1007/s11367016-1199-1

Preiss P, Friedrich R, Klotz V (2008) Deliverable n 1.1 - RS 3a "Report on the procedure and data to generate averaged/aggregated data". NEEDS New Energy Externalities Developments for Sustainability

Rabl A, Hirschberg S, Desaigues B, Markandya A, Nocker L de (2004) New elements for the assessment of external costs from energy technologies NewExt. Final Report to the European Commission, DG Research, Technological Development and Demonstration (RTD)

Reid WV, Sarukhán J, Whythe A (2005) Living beyond our means. Natural assets and human well-being. Statement from the Board

Rennings K, Wiggering H (1997) Steps towards indicators of sustainable development: Linking economic and ecological concepts. Ecol Econ 20:25-36

Schneider-Marin P, Dotzler C, Röger C, Lang W, Glöggler J, Meier K, Runkel S (2019) Design2Eco| Schlussbericht. Lebenszyklusbetrachtung im Planungsprozess von Büro- und Verwaltungsgebäuden - Entscheidungsgrundlagen und Optimierungsmöglichkeiten für frühe Planungsphasen

Schultz H, Lübking D, Brockenhagen D (2015) Anforderungen an und Grenzen von $\mathrm{CO}_{2}$-Kompensation. Analyse, Kriterien und Leitfaden für sinnvolle Kompensation

Steen B (2006) Describing values in relation to choices in LCA (7 pp). Int J Life Cycle Assess 11(4):277-283. https://doi.org/10.1065/ lca2005.10.227

Steen B, Palander S (2015) EPS-2015d-including-climate-impacts-fromsecondary-particles. https://www.lifecyclecenter.se/publications/ eps-2015d1-excluding-climate-impacts-from-secondary-particles/. Accessed 04 Jan 2020
Steen B, Palander S (2016) A selection of safeguard subjects and state indicators for sustainability assessments. Int J Life Cycle Assess 21(6):861-874. https://doi.org/10.1007/s11367-016-1052-6

Ströbele B (2013) Grenzen des Carbon Footprint für die Bewertung des ökologischen Bauens. Bauphysik 35(5):338-345. https://doi.org/10. 1002/bapi.201310076

Swarr TE, Hunkeler D, Klöpffer W, Pesonen H-L, Ciroth A, Brent AC, Pagan R (2011) Environmental life-cycle costing: a code of practice. Int J Life Cycle Assess 16(5):389-391. https://doi.org/10.1007/ s11367-011-0287-5

Tekie H, Lindblad M (2013) Methodologies for monetary valuation of environmental impacts, Gothenburg, Schweden

the Bruyn S, Ahdour S, Bijleveld M, de Graaf L, Schep E, Schroten A, Vergeer R (2018) Environmental Prices Handbook 2017. Methods and numbers for valuation of environmental impacts, Delft

Ulmer S, Streck S, Sutter P (2010) Externe Kosten im Hochbau. BMVBS-Online-Publikation 17/2010, Berlin

van Oers L, Guinée J (2016) The abiotic depletion potential: background, updates, and future. Resources 5(1):16. https://doi.org/10.3390/ resources 5010016

van Oers L, Koning Ad, Guinée JB, Huppes G (2002) Abiotic resource depletion in LCA. Improving characterisation factors for abiotic resource depletion as recommended in the new Dutch LCA handbook

Vogtländer J (2016) A practical guide to LCA for students designers and business managers, cradle-to-grave and cradle-to-cradle. Appendix IV. Delft Academic Press, Delft

Vogtländer J (2017) ecocosts 2017_V1-6 midpoint tables. http://www. ecocostsvalue.com/EVR/model/theory/subject/5-data.html. Accessed 19 Nov 2019

Vogtländer J, Bijma A (2000) The virtual pollution prevention costs '99'. A single LCA-based indicator for emissions. Int $\mathrm{J}$ Life Cycle Assessment 5(2):113-124

Vogtländer J, Brezet HC, Hendricks CF (2001) The virtual eco-costs - a single LCA-based indicator for sustainability and the eco-costsvalue ratio (EVR) model for economic allocation. A New LCABased Calculation Model to Determine the Sustainability of Products and Services. Int J Life Cycle Assess 6(3):157-166. https://doi.org/10.1065/Ica2000.011.042

Weidema BP (2009) Using the budget constraint to monetarise impact assessment results. Ecol Econ 68(6):1591-1598. https://doi.org/10. 1016/j.ecolecon.2008.01.019

Weidema BP, Finnveden G, Stewart M (2005) Impacts from resource use - a common position paper. Int J Life Cycle Assess 10(6):382. https://doi.org/10.1065/lca2005.11.003

Weissenberger M, Jensch W, Lang W, Weißenberger M (2014) The convergence of life cycle assessment and nearly zero-energy buildings: The case of Germany. Energy Build 76:551-557. https://doi. org/10.1016/j.enbuild.2014.03.028

Publisher's note Springer Nature remains neutral with regard to jurisdictional claims in published maps and institutional affiliations. 